\title{
Single-step ethanol production from lignocellulose using novel extremely thermophilic bacteria
}

\author{
Vitali A Svetlitchnyi", Oliver Kensch, Doris A Falkenhan, Svenja G Korseska, Nadine Lippert, Melanie Prinz, \\ Jamaleddine Sassi, Anke Schickor and Simon Curvers
}

\begin{abstract}
Background: Consolidated bioprocessing (CBP) of lignocellulosic biomass to ethanol using thermophilic bacteria provides a promising solution for efficient lignocellulose conversion without the need for additional cellulolytic enzymes. Most studies on the thermophilic CBP concentrate on co-cultivation of the thermophilic cellulolytic bacterium Clostridium thermocellum with non-cellulolytic thermophilic anaerobes at temperatures of $55^{\circ} \mathrm{C}-60^{\circ} \mathrm{C}$.

Results: We have specifically screened for cellulolytic bacteria growing at temperatures $>70^{\circ} \mathrm{C}$ to enable direct conversion of lignocellulosic materials into ethanol. Seven new strains of extremely thermophilic anaerobic cellulolytic bacteria of the genus Caldicellulosiruptor and eight new strains of extremely thermophilic xylanolytic/ saccharolytic bacteria of the genus Thermoanaerobacter isolated from environmental samples exhibited fast growth at $72^{\circ} \mathrm{C}$, extensive lignocellulose degradation and high yield ethanol production on cellulose and pretreated lignocellulosic biomass. Monocultures of Caldicellulosiruptor strains degraded up to 89-97\% of the cellulose and hemicellulose polymers in pretreated biomass and produced up to $72 \mathrm{mM}$ ethanol on cellulose without addition of exogenous enzymes. In dual co-cultures of Caldicellulosiruptor strains with Thermoanaerobacter strains the ethanol concentrations rose 2- to 8.2-fold compared to cellulolytic monocultures. A co-culture of Caldicellulosiruptor DIB 087C and Thermoanaerobacter DIB 097X was particularly effective in the conversion of cellulose to ethanol, ethanol comprising 34.8 mol\% of the total organic products. In contrast, a co-culture of Caldicellulosiruptor saccharolyticus DSM 8903 and Thermoanaerobacter mathranii subsp. mathranii DSM 11426 produced only low amounts of ethanol.

Conclusions: The newly discovered Caldicellulosiruptor sp. strain DIB 004C was capable of producing unexpectedly large amounts of ethanol from lignocellulose in fermentors. The established co-cultures of new Caldicellulosiruptor strains with new Thermoanaerobacter strains underline the importance of using specific strain combinations for high ethanol yields. These co-cultures provide an efficient CBP pathway for ethanol production and represent an ideal starting point for development of a highly integrated commercial ethanol production process.
\end{abstract}

Keywords: Anaerobic, Caldicellulosiruptor, Consolidated bioprocessing, Ethanol, Extremely thermophilic bacteria, High temperature, Lactate, Lignocellulose, Thermoanaerobacter

\section{Background}

Ethanol is an established alternative fuel from renewable resources [1]. Today it is mainly produced from sugar or starchy biomass, limiting the environmental benefit [2] and posing a competition for the raw materials with food industry. In the last decade research efforts have mounted to replace this 1 st generation ethanol by the 2nd generation ethanol made from lignocellulosic feedstocks, including pretreatment, enzymatic hydrolysis, sugar fermentation and

* Correspondence: Vitali.Svetlitchnyi@direvo.com

Direvo Industrial Biotechnology GmbH, Nattermannallee 1, D-50259, Köln, Germany

process design. Most of the processes developed toward industrial scale involve addition of enzymes for cellulose and hemicellulose hydrolysis and use of specific yeast strains engineered to utilize C5 and C6 sugars. Both achieving effective biomass hydrolysis and complete sugar conversion are essential for an economical process. Although enzyme producers have made substantial improvements in the recent years, cost of cellulase enzymes are still in the range of $\$ 0.5$ to $\$ 1.0$ per gallon of 2 nd generation ethanol $[3,4]$.

A process strategy that aims to circumvent this critical cost-increasing item is the consolidated bioprocessing approach [3,5]. In CBP an organism or a mixed culture 
of organisms produces enzymes for hydrolysis of cellulose and hemicellulose in lignocellulosic biomass and ferments the C5 and C6 sugars into ethanol or other valuable products without addition of cellulolytic or hemicellulolytic enzymes. Several mesophilic and thermophilic cellulolytic as well as non-cellulolytic microorganisms with engineered cellulase activity are under development for the application in CBP $[3,6]$.

Until now, the most well developed candidate for thermophilic CBP is the anaerobic thermophilic cellulolytic bacterium Clostridium thermocellum [7-9]. Because C. thermocellum is unable to ferment C5 sugars [7], co-cultures with C5 sugar fermenting thermophilic ethanologenic bacteria of the genera Thermoanaerobacterium [8,10,11] and Thermoanaerobacter [12,13] have been developed to increase ethanol yield from cellulose and hemicellulose. Co-cultures of engineered $C$. thermocellum and Thermoanaerobacterium saccharolyticum produced $38.1 \mathrm{~g} / \mathrm{l}$ ethanol from Avicel (crystalline cellulose), which is the highest ethanol concentration reported for a thermophilic, cellulolytic co-culture to date [8]. However, the performance of these monocultures and co-cultures was not evaluated with real lignocellulosic substrates under industrial conditions and few data have been reported yet for C. thermocellum co-cultures that would support the process viability using pretreated and untreated lignocellulosic substrates under laboratory conditions $[11,13]$.

Realization of CBP at extremely high temperatures $\left(>70^{\circ} \mathrm{C}\right)$ would offer several advantages over mesophilic and thermophilic $\left(50^{\circ} \mathrm{C}-60^{\circ} \mathrm{C}\right)$ conditions: increased stability of enzymes and organisms, decreased medium viscosity, no requirement for cooling, elimination of pathogenic bacteria, low risk of contamination and facilitated continuous product recovery $[13,14]$.

Extremely thermophilic (temperature optimum for growth $>70^{\circ} \mathrm{C}$ ) cellulolytic bacteria of the genus Caldicellulosiruptor and non-cellulolytic bacteria of the genera Thermoanaerobacterium and Thermoanaerobacter were also studied as potential CBP organisms. Caldicellulosiruptor species effectively hydrolyze both cellulose and hemicelluloses, metabolize C5 and C6 sugars and can grow on pretreated as well as on untreated lignocellulosic materials like switchgrass and poplar [15-18]. They produce lactate, acetate, $\mathrm{H}_{2}$ and $\mathrm{CO}_{2}$, whereas ethanol is detected only in trace amounts [15-17]. Because of very low ethanol production by known Caldicellulosiruptor species, they have so far been investigated primarily for conversion of lignocellulose to $\mathrm{H}_{2}$ [15]. However, because of their high growth temperature and hydrolytic capabilities Caldicellulosiruptor species have a high potential in production of ethanol from lignocellulose. Thermoanaerobacterium and Thermoanaerobacter species [19-21] hydrolyze hemicellulose (e.g. xylan) and ferment C5 and
C6 sugars to ethanol as major fermentation product. For T. saccharolyticum, a genetic tool to produce ethanol at high yield was recently developed [19].

Here we present the results of screening for extremely thermophilic bacteria enabling direct conversion of lignocellulosic biomass to ethanol at $>70^{\circ} \mathrm{C}$. We demonstrate ethanol production by newly isolated Caldicellulosiruptor and Thermoanaerobacter strains on various pretreated lignocellulosic materials in monocultures and established dual co-cultures.

\section{Results}

Enrichment of extremely thermophilic bacteria for conversion of lignocellulosic substrates to ethanol

For cellulolytic enrichments, media with filter paper strips and untreated beech wood as substrate were inoculated with more than 200 environmental samples. After incubation at $72^{\circ} \mathrm{C}$ for 7 days under anaerobic conditions, numerous cultures displayed decomposition of filter paper. For the enrichment of cellulolytic bacteria resistant against inhibitors present in pretreated lignocellulosic biomass [22], the cultures were grown on media containing unwashed dilute acid steam-explosion -pretreated poplar wood followed by serial dilutions. From 39 cellulolytic enrichment cultures obtained from the highest dilutions, 11 cultures produced substantial amounts of ethanol upon growth on filter paper as well as on steam-explosion-pretreated poplar wood (Additional file 1: Table S1). These cultures were selected for isolation of ethanologenic bacteria.

\section{Composition of ethanologenic enrichment cultures}

Seven strains of cellulolytic bacteria and eight strains of non-cellulolytic bacteria were isolated from the ethanologenic enrichments. Based on 16S rRNA gene sequence analysis, all cellulolytic strains belonged to the genus Caldicellulosiruptor (Figure 1): str. DIB 004C, DSM 25177, GenBank accession number JX988415; str. DIB 041C, DSM 25771, GenBank accession number JX988416; str. DIB 087C, DSM 25772, GenBank accession number JX988417; str. DIB 101C, DSM 25178, GenBank accession number JX988418; str. DIB 103C, DSM 25773, GenBank accession number JX988419; str. DIB 104C, DSM 25774, GenBank accession number JX988420; str. DIB 107C, DSM 25775, GenBank accession number JX988421. The closest relative of all isolates was Caldicellulosiruptor saccharolyticus str. Tp8T.6331 (DSM 8903) [23] with 16S rRNA gene sequence identity ranging from $96.7 \%$ (strain DIB 041C) to $99.3 \%$ (strains DIB 004C, DIB 101C and DIB 103C).

All isolated non-cellulolytic strains were members of the genus Thermoanaerobacter (Figure 2): str. DIB 004G, DSM 25179, GenBank accession number JX988422; str. DIB 087G, DSM 25777, GenBank 


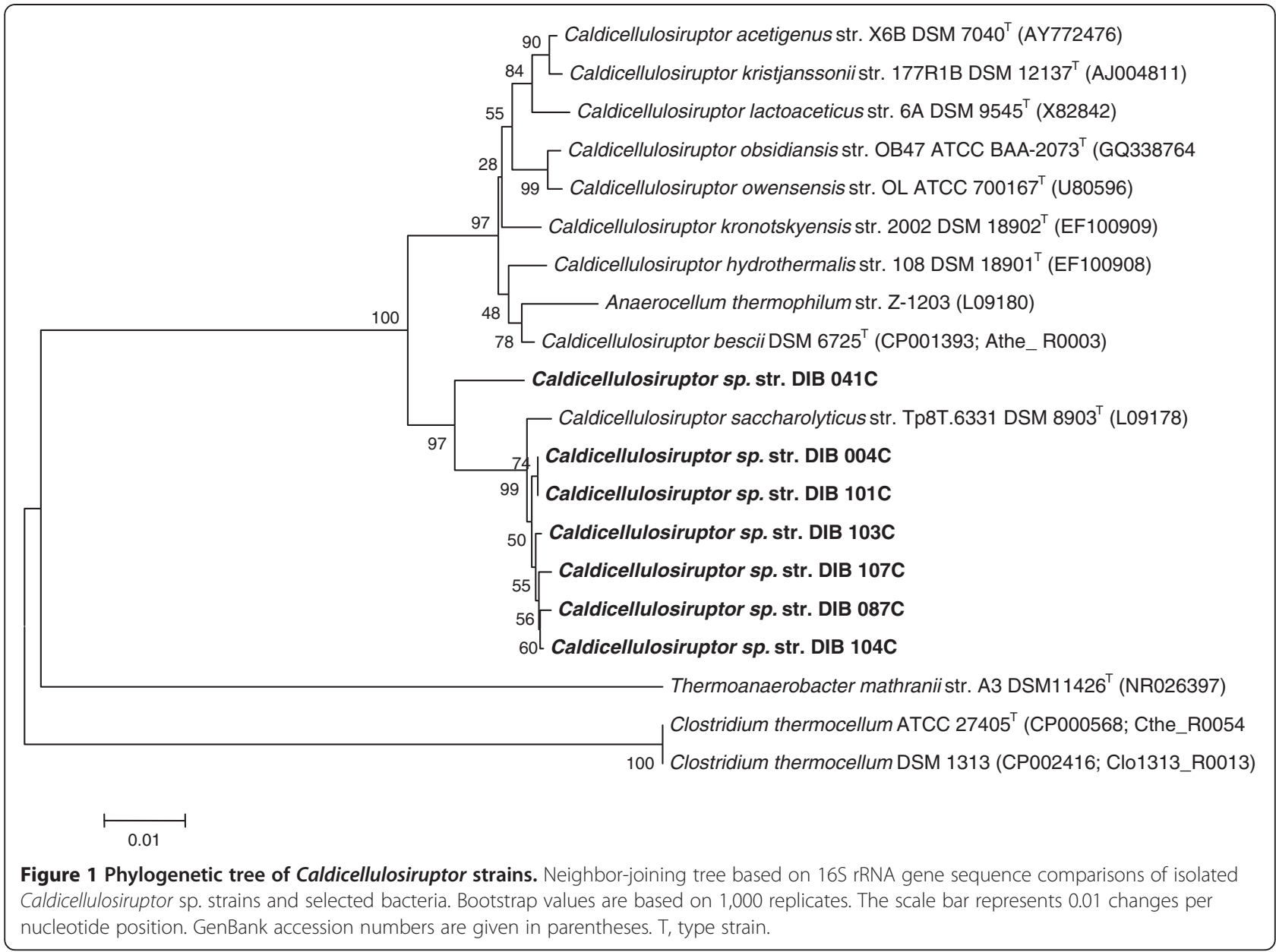

accession number JX988423; str. DIB 101G, DSM 25180, GenBank accession number JX988425; str. DIB 097X, DSM 25308, GenBank accession number JX988424; str. DIB 101X, DSM 25181, GenBank accession number JX988426; str. DIB 103X, DSM 25776, GenBank accession number JX988427; str. DIB 104X, DSM 25778, GenBank accession number JX988428; str. DIB 107X, DSM 25779, GenBank accession number JX988429. The closest relative of the strains DIB 004G, DIB 097X, DIB101X, DIB 103X and DIB 107X was the xylanolytic bacterium Thermoanaerobacter mathranii subsp. mathranii str. A3 (DSM 11426T) [20] with identity range of $99.2 \%$ to $99.4 \%$. Strains DIB 101G, DIB 087G and DIB 104X clustered with the xylanolytic bacterium Thermoanaerobacter thermohydrosulfuricus str. E100-69 (DSM 567T) [21] with identities of 99.4\%-99.5\%.

All isolated Caldicellulosiruptor sp. strains grew well at $72^{\circ} \mathrm{C}$ on crystalline cellulose (Avicel and filter paper), cellobiose, glucose, xylan and xylose, forming lactate, acetate and ethanol as organic fermentation products. When grown in Hungate tubes, lactate was generally the main fermentation product, followed by acetate and ethanol (Table 1 and Additional file 1: Table S2). In this respect, the isolated strains were similar to $C$. saccharolyticus DSM 8903 used as a control (Table 1).

All isolated Thermoanaerobacter sp. strains did not utilize cellulose, grew well at $72^{\circ} \mathrm{C}$ and differed in their ability to utilize xylan (Table 1 and Additional file 1: Table S2). Saccharolytic strains DIB 004G, DIB 087G and DIB 101G grew on cellobiose, glucose and xylose, but not on xylan. Xylanolytic strains DIB 097X, DIB 101X, DIB 103X, DIB 104X and DIB 107X grew on cellobiose, glucose, xylan and xylose. On all substrates tested, isolated Thermoanaerobacter sp. strains generated ethanol, lactate and acetate as organic fermentation products. When grown in Hungate tubes ethanol was the main fermentation product of strains DIB 004G, DIB 097X, DIB 101G, DIB 101X, DIB 103X and DIB 107X (Table 1 and Additional file 1: Table S2). Lactate was the main fermentation product of strain DIB 087G. Strain DIB 104X produced almost equal amounts of ethanol and lactate. In this respect, DIB 104X was similar to the well known ethanologenic bacterium $T$. mathranii DSM 11426 used as a control (Table 1). 


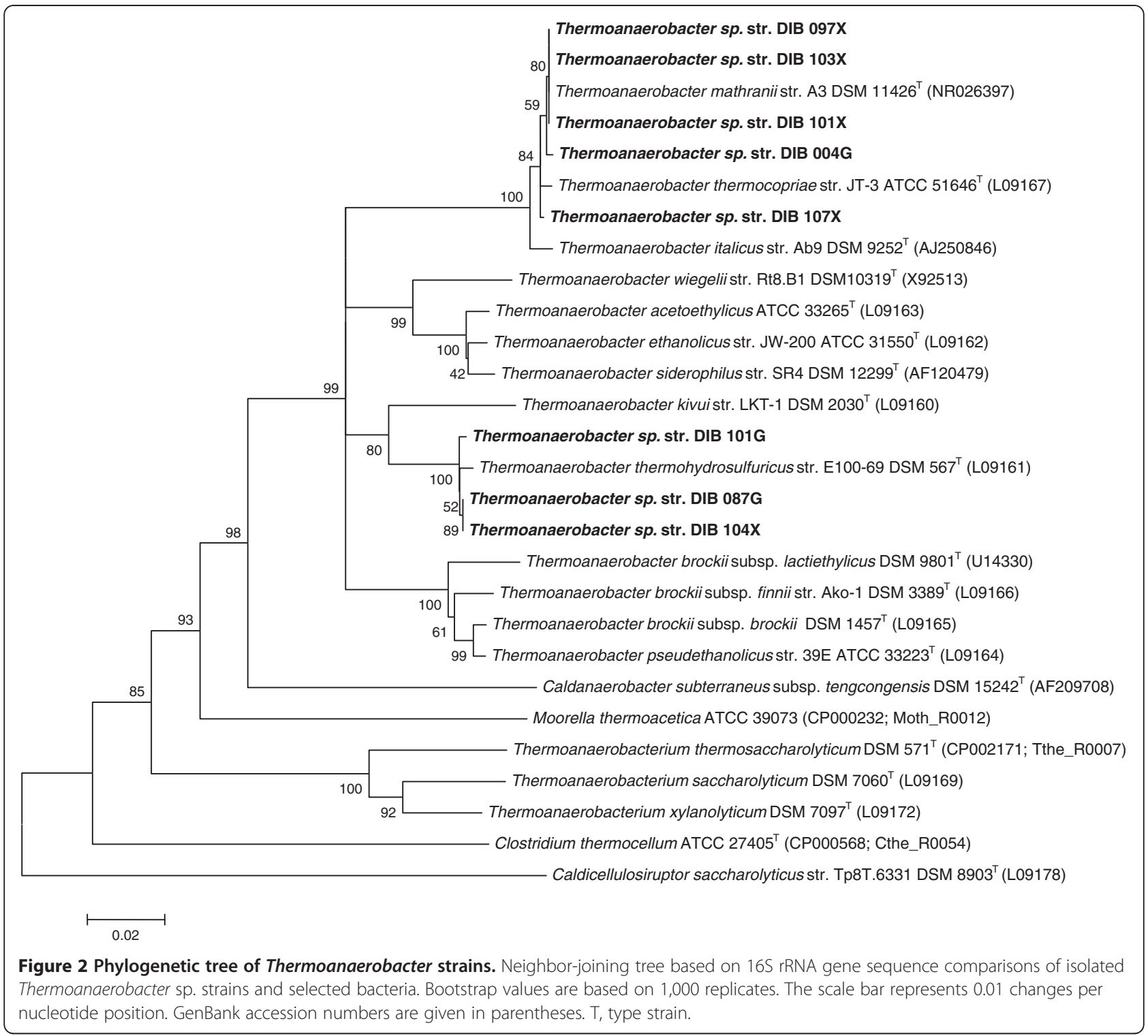

Growth on pretreated washed lignocellulosic substrates

Natural lignocellulosic biomass (e.g. wood, straw, grass) requires high-temperature pretreatment to make insoluble carbohydrate polymers accessible to hydrolytic enzymes. However, Yang et al. demonstrated growth of Caldicellulosiruptor bescii (formerly Anaerocellum thermophilum) on untreated poplar and switchgrass [17].

We have tested the ability of cellulolytic Caldicellulosiruptor strains DIB 004C and DIB 101C to ferment insoluble carbohydrates from dilute sulfurous acid steam-explosion-pretreated substrates (Table 2 and Additional file 1: Tables S3 and S4). To remove soluble carbohydrates, pretreated substrates (poplar, spruce, miscanthus, wheat straw, whole corn plants, corn cobs, corn stalks, sugarcane bagasse, sweet sorghum, cotton stalks) were washed extensively with hot water. The remaining insoluble material was used as the sole fermentable substrate for cultivation of the bacteria. Strains DIB 004C and DIB 101C grew well on all these materials and produced lactate, acetate and ethanol indicating utilization of insoluble carbohydrates present in the washed substrates.

Table 2 shows the fermentation products of strain Caldicellulosiruptor DIB 004C upon growth on medium with $2.9 \mathrm{~g} / \mathrm{l}$ of washed pretreated poplar. This material contained $58.1 \%$ glucan, $0.1 \%$ xylan, $0.2 \%$ galactan, $2.7 \%$ acid-soluble lignin, 34.8\% acid-insoluble lignin, and $0.1 \%$ lignin ash, as determined by standard laboratory methods [24]. At $2.9 \mathrm{~g} / \mathrm{l}$ of washed pretreated poplar, the medium contained $10.4 \mathrm{mM}$ glucose, $0.02 \mathrm{mM}$ xylose, and $0.03 \mathrm{mM}$ galactose equivalents. Assuming a theoretical yield of $2.0 \mathrm{~mol}$ of lactate+acetate+ethanol per mol 
Table 1 Fermentation products of cellulolytic and non-cellulolytic strains isolated from ethanologenic enrichment cultures

\begin{tabular}{|c|c|c|c|c|c|c|c|c|c|c|c|}
\hline \multirow{2}{*}{$\begin{array}{l}\text { Enrichment } \\
\text { cultures used } \\
\text { for isolation }\end{array}$} & \multirow[t]{2}{*}{ Substrate } & \multicolumn{5}{|c|}{ Isolated cellulolytic Caldicellulosiruptor sp. strains } & \multicolumn{5}{|c|}{ Isolated non-cellulolytic Thermoanaerobacter sp. strains } \\
\hline & & Strain & Ethanol $\mathrm{mM}$ & Acetate $\mathrm{mM}$ & Lactate $\mathrm{mM}$ & $\begin{array}{c}\text { Ethanol:Acetate: } \\
\text { Lactate mM:mM:mM }\end{array}$ & Strain & Ethanol $\mathrm{mM}$ & Acetate $\mathrm{mM}$ & Lactate $\mathrm{mM}$ & $\begin{array}{c}\text { Ethanol:Acetate: } \\
\text { Lactate } \mathrm{mM}: \mathrm{mM}: \mathrm{mM}\end{array}$ \\
\hline \multirow[t]{5}{*}{$\# 4$} & $\begin{array}{c}\text { Cellulose } \\
\text { (26 mM gluc.equiv.) }\end{array}$ & DIB004C & $1.6 \pm 0.7$ & $4.8 \pm 0.5$ & $9.6 \pm 0.1$ & $1: 3.0: 6.1$ & DIB004G & \multicolumn{4}{|c|}{ no growth on cellulose } \\
\hline & $\begin{array}{c}\text { Cellobiose } \\
\text { (25 mM gluc. equiv.) }\end{array}$ & & $0.3 \pm 0.2$ & $8.6 \pm 0.1$ & $18.8 \pm 0.1$ & $1: 29.7: 64.7$ & & $21.6 \pm 0.6$ & $2.4 \pm 0.1$ & $17.1 \pm 0.1$ & $1: 0.1: 0.8$ \\
\hline & Glucose (25 mM) & & $1.2 \pm 0.1$ & $6.4 \pm 0.2$ & $19.6 \pm 0.5$ & $1: 5.2: 15.9$ & & $23.2 \pm 0.2$ & $0.7 \pm 0.1$ & $17.9 \pm 0.7$ & $1: 0.0: 0.8$ \\
\hline & $\begin{array}{c}\text { Xylan } \\
\text { (31 mM xylose equiv.) }\end{array}$ & & $1.5 \pm 0.2$ & $9.6 \pm 1.0$ & $13.2 \pm 3.1$ & $1: 6.5: 9.0$ & & \multicolumn{4}{|c|}{ no growth on xylan } \\
\hline & Xylose (30 mM) & & $3.2 \pm 0.4$ & $2.5 \pm 0.9$ & $18.6 \pm 0.1$ & $1: 0.8: 5.9$ & & $17.1 \pm 0.4$ & $0.0 \pm 0.0$ & $10.3 \pm 0.0$ & $1: 0.00: 0.6$ \\
\hline \multirow[t]{5}{*}{ \#97 } & $\begin{array}{c}\text { Cellulose } \\
\text { (26 mM gluc.equiv.) }\end{array}$ & \multicolumn{5}{|c|}{ no cellulolytic strains isolated } & DIB097X & \multicolumn{4}{|c|}{ no growth on cellulose } \\
\hline & $\begin{array}{c}\text { Cellobiose } \\
\text { (25 mM gluc. equiv.) }\end{array}$ & & & & & & & $29.2 \pm 0.2$ & $5.3 \pm 1.0$ & $8.9 \pm 0.3$ & $1: 0.2: 0.3$ \\
\hline & Glucose (25 mM) & & & & & & & $31.7 \pm 0.7$ & $2.8 \pm 0.4$ & $11.9 \pm 0.0$ & $1: 0.1: 0.4$ \\
\hline & $\begin{array}{c}\text { Xylan } \\
\text { (31 mM xylose equiv.) }\end{array}$ & & & & & & & $19.8 \pm 0.6$ & $9.0 \pm 0.1$ & $5.1 \pm 0.0$ & $1: 0.5: 0.3$ \\
\hline & Xylose (30 mM) & & & & & & & $25.5 \pm 2.0$ & $1.1 \pm 0.3$ & $8.2 \pm 1.5$ & $1: 0.0: 0.3$ \\
\hline \multirow[t]{5}{*}{$\# 101$} & $\begin{array}{c}\text { Cellulose } \\
\text { (26 mM gluc.equiv.) }\end{array}$ & DIB101C & $1.1 \pm 0.1$ & $6.9 \pm 0.1$ & $6.6 \pm 0.6$ & $1: 6.4: 6.2$ & \multicolumn{5}{|c|}{ see Additional file 1: Table S2 for further details } \\
\hline & $\begin{array}{c}\text { Cellobiose } \\
\text { (25 mM gluc. equiv.) }\end{array}$ & & $2.6 \pm 0.5$ & $11.1 \pm 0.1$ & $14.8 \pm 0.1$ & $1: 4.2: 5.6$ & & & & & \\
\hline & Glucose (25 mM) & & $1.5 \pm 0.0$ & $9.7 \pm 0.6$ & $12.7 \pm 0.5$ & $1: 6.6: 8.6$ & & & & & \\
\hline & $\begin{array}{c}\text { Xylan } \\
\text { (31 mM xylose equiv.) }\end{array}$ & & $2.2 \pm 0.2$ & $10.0 \pm 0.3$ & $9.4 \pm 0.2$ & $1: 4.5: 4.3$ & & & & & \\
\hline & Xylose (30 mM) & & $5.1 \pm 0.8$ & $4.8 \pm 0.7$ & $10.5 \pm 0.0$ & $1: 0.9: 2.1$ & & & & & \\
\hline \multirow[t]{5}{*}{ Control strains } & $\begin{array}{c}\text { Cellulose } \\
\text { (26 mM gluc.equiv.) }\end{array}$ & $\begin{array}{l}\text { Caldicellu- } \\
\text { losiruptor }\end{array}$ & $1.4 \pm 0.3$ & $5.7 \pm 0.1$ & $6.6 \pm 0.1$ & $1: 4.1: 4.7$ & \multirow{5}{*}{$\begin{array}{l}\text { Thermoana- } \\
\text { erobacter } \\
\text { mathranii } \\
\text { DSM11426 }\end{array}$} & \multicolumn{4}{|c|}{ no growth on cellulose } \\
\hline & $\begin{array}{c}\text { Cellobiose } \\
\text { (25 mM gluc. equiv.) }\end{array}$ & $\begin{array}{l}\text { saccharolyticus } \\
\text { DSM } 8903\end{array}$ & $4.7 \pm 0.3$ & $7.1 \pm 1.5$ & $14.4 \pm 2.0$ & $1: 1.5: 3.0$ & & $12.4 \pm 0.3$ & $7.2 \pm 0.5$ & $18.7 \pm 1.2$ & $1: 0.6: 1.5$ \\
\hline & Glucose (25 mM) & & $1.7 \pm 0.2$ & $7.8 \pm 1.1$ & $14.2 \pm 3.7$ & $1: 4.7: 8.6$ & & $17.2 \pm 0.4$ & $8.5 \pm 0.5$ & $17.0 \pm 1.3$ & $1: 0.5: 1.0$ \\
\hline & $\begin{array}{c}\text { Xylan } \\
\text { (31 mM xylose equiv.) }\end{array}$ & & $1.8 \pm 0.3$ & $10.2 \pm 0.4$ & $7.7 \pm 0.3$ & $1: 5.5: 4.2$ & & $19.9 \pm 0.7$ & $4.9 \pm 0.4$ & $2.7 \pm 0.0$ & $1: 0.2: 0.1$ \\
\hline & Xylose (30 mM) & & $2.9 \pm 0.5$ & $4.1 \pm 0.8$ & $14.7 \pm 1.3$ & $1: 1.4: 5.1$ & & $13.7 \pm 0.0$ & $4.9 \pm 0.1$ & $12.6 \pm 0.6$ & $1: 0.4: 0.9$ \\
\hline
\end{tabular}

Cultures were grown at $72^{\circ} \mathrm{C}$ for 6 days in Hungate tubes without shaking. Experiments were performed in duplicates. 
Table 2 Fermentation products of Caldicellulosiruptor DIB004C alone and in co-cultures with Thermoanaerobacter DIB004G and DIB097X

\begin{tabular}{|c|c|c|c|c|c|c|c|}
\hline \multirow[t]{2}{*}{ Culture } & \multirow[t]{2}{*}{ Substrate } & \multicolumn{6}{|c|}{ Fermentation products } \\
\hline & & Ethanol $\mathrm{mM}$ & Acetate $\mathrm{mM}$ & Lactate $\mathrm{mM}$ & $\begin{array}{c}\text { Ethanol:Acetate: } \\
\text { Lactate mM:mM:mM }\end{array}$ & $\begin{array}{c}\text { Total } \\
\text { products } \mathrm{mM}\end{array}$ & $\begin{array}{c}\text { Ethanol } \\
\text { yield mol\% }\end{array}$ \\
\hline DIB004C & \multirow[t]{5}{*}{ Avicel $(10 \mathrm{~g} / \mathrm{l})$} & $2.7 \pm 0.2$ & $21.4 \pm 0.1$ & $9.0 \pm 0.1$ & $1: 8.0: 3.4$ & $33.0 \pm 0.0$ & $8.1 \pm 0.5$ \\
\hline DIB004G & & \multicolumn{6}{|c|}{ no growth } \\
\hline DIB097X & & \multicolumn{6}{|c|}{ no growth } \\
\hline $\mathrm{DIB004C+DIB004G}$ & & $8.8 \pm 0.7$ & $19.9 \pm 0.1$ & $11.0 \pm 0.6$ & $1: 2.3: 1.3$ & $39.7 \pm 1.1$ & $22.1 \pm 1.3$ \\
\hline DIB004C+DIB097X & & $10.3 \pm 0.7$ & $18.6 \pm 0.7$ & $11.8 \pm 0.6$ & $1: 1.8: 1.1$ & $40.7 \pm 0.8$ & $25.4 \pm 1.1$ \\
\hline DIB004C & \multirow{5}{*}{$\begin{array}{l}\text { washed pretreated } \\
\text { poplar }(2.9 \mathrm{~g} / \mathrm{l})\end{array}$} & $1.5 \pm 0.1$ & $10.9 \pm 0.2$ & $6.2 \pm 0.8$ & $1: 7.2: 4.1$ & $18.6 \pm 0.8$ & $8.1 \pm 1.0$ \\
\hline DIB004G & & \multicolumn{6}{|c|}{ no growth } \\
\hline DIB097X & & \multicolumn{6}{|c|}{ no growth } \\
\hline $\mathrm{DIB004C+D|B004G}$ & & $5.7 \pm 0.3$ & $14.0 \pm 0.2$ & $6.6 \pm 0.9$ & $1: 2.5: 1.2$ & $26.3 \pm 1.4$ & $21.7 \pm 0.1$ \\
\hline DIB004C+DIB097X & & $3.7 \pm 0.2$ & $14.1 \pm 0.4$ & $8.3 \pm 1.3$ & $1: 3.9: 2.3$ & $26.1 \pm 1.5$ & $14.0 \pm 1.6$ \\
\hline DIB004C & \multirow{5}{*}{$\begin{array}{l}\text { unwashed pretreated } \\
\text { poplar }(10 \mathrm{~g} / \mathrm{l})\end{array}$} & $2.6 \pm 0.2$ & $12.0 \pm 0.2$ & $6.1 \pm 0.2$ & $1: 4.6: 2.3$ & $20.7 \pm 0.2$ & $12.6 \pm 1.0$ \\
\hline DIB004G & & $4.3 \pm 0.3$ & $4.4 \pm 0.6$ & $3.0 \pm 0.1$ & $1: 1.0: 0.7$ & $11.7 \pm 0.4$ & $37.0 \pm 3.8$ \\
\hline DIB097X & & $5.1 \pm 0.1$ & $4.3 \pm 0.3$ & $0.0 \pm 0.0$ & $1: 0.8: 0.0$ & $9.4 \pm 0.2$ & $54.5 \pm 2.2$ \\
\hline $\mathrm{DIB004C+DIB004G}$ & & $5.7 \pm 0.4$ & $11.6 \pm 0.1$ & $3.1 \pm 0.0$ & $1: 2.0: 0.5$ & $20.4 \pm 0.4$ & $27.9 \pm 1.2$ \\
\hline DIB004C+DIB097X & & $7.0 \pm 0.1$ & $11.4 \pm 0.2$ & $3.5 \pm 0.4$ & $1: 1.6: 0.5$ & $21.8 \pm 0.6$ & $32.1 \pm 0.6$ \\
\hline
\end{tabular}

Cultures were grown at $72^{\circ} \mathrm{C}$ for 6 days in flasks with shaking at $100 \mathrm{rpm}$. Experiments were performed in duplicates.

of glucose or galactose and $1.67 \mathrm{~mol}$ of lactate+acetate +ethanol per mol of xylose, formation of a maximum of $20.9 \mathrm{mM}$ lactate+acetate+ethanol could be expected. After 6 days of incubation, strain DIB 004C produced $6.2 \mathrm{mM}$ lactate, $10.9 \mathrm{mM}$ acetate and $1.5 \mathrm{mM}$ ethanol (18.6 mM lactate+acetate+ethanol) which corresponded to utilization of $89.1 \%$ of insoluble cellulose and hemicellulose in pretreated poplar (Table 2).

Similar to washed pretreated poplar, high levels of utilization of insoluble cellulose and hemicellulose fractions in pretreated washed spruce, miscanthus, wheat straw, whole corn plants, corn cobs, corn stalks, sugarcane bagasse, sweet sorghum and cotton stalks (all at $2.9 \mathrm{~g} / \mathrm{l}$ ) were observed with cellulolytic Caldicellulosiruptor strains DIB 004C and DIB 101C (Additional file 1: Table S4). The highest levels of carbohydrate utilization were reached on spruce (97\%), corn cobs (97\%) and corn stalks (93\%).

The non-cellulolytic strains Thermoanaerobacter DIB 004G and DIB 097X did not grow on washed pretreated poplar (Table 2) and other washed pretreated substrates confirming complete removal of soluble carbohydrates by the applied washing procedure.

\section{Growth on pretreated unwashed substrates}

The ability to ferment pretreated unwashed lignocellulosic substrates was investigated with Caldicellulosiruptor DIB 004C and Thermoanaerobacter DIB 004G and DIB 097X. The bacteria grew well on $10 \mathrm{~g} / \mathrm{l}$ of all unwashed dilute sulfurous acid steam-explosion-pretreated substrates tested (poplar, spruce, miscanthus, wheat straw, whole corn plants, corn cobs, corn stalks, sugarcane bagasse, sweet sorghum, cotton stalks), as well as on untreated dried distillers grains with solubles (DDGS) and waste paper (only DIB 004C on the last substrate). Growth was obvious from the increase of turbidity and pressure, decrease of $\mathrm{pH}$ and production of ethanol, lactate and acetate (Table 2 and Additional file 1: Table S3).

Total concentrations of fermentation products formed by non-cellulolytic strains DIB 004G and DIB 097X were generally lower than the concentrations achieved with the cellulolytic strain DIB 004C (Table 2 and Additional file 1: Table S3) indicating utilization of cellulose by strain DIB 004C in pretreated materials. Similar to growth on defined substrates (Table 1), ethanol production by strain DIB $004 \mathrm{C}$ on pretreated substrates in flasks without $\mathrm{pH}$ control was relatively low (7 to $13 \mathrm{~mol} \%$ ethanol from organic fermentation products lactate+acetate+ethanol), whereas ethanol production by ethanologenic DIB 004G and DIB 097X was high (23 to $63 \mathrm{~mol} \%$ ethanol), see Table 2 and Additional file 1: Table S3.

Ethanol production by co-cultures of Caldicellulosiruptor and Thermoanaerobacter strains on lignocellulosic substrates grown without $\mathrm{pH}$ control in flasks

Cellulolytic and non-cellulolytic ethanologenic strains were isolated from ethanologenic enrichments (Table 1 and Additional file 1: Table S2) indicating coexistence of these organisms in their natural habitats. Extracellular hydrolysis of cellulose by Caldicellulosiruptor strains in 
these enrichments obviously supports the growth of non-cellulolytic ethanologenic Thermoanaerobacter strains resulting in natural cellulolytic ethanologenic cocultures.

We employed several of the isolated Caldicellulosiruptor and Thermoanaerobacter strains to establish defined dual co-cultures and tested their potential for ethanol production from Avicel and several lignocellulosic substrates (Figure 3, Table 2 and Additional file 1: Table S3). Different co-cultures were analyzed under batch conditions in flasks without $\mathrm{pH}$ control.

Table 2 and Additional file 1: Table S3 show fermentation products upon growth of single cellulolytic strain DIB 004C, single non-cellulolytic strains DIB 004G or DIB 097X as well as co-cultures DIB 004C + DIB 004G and DIB 004C + DIB 097X on Avicel, washed pretreated poplar, several pretreated unwashed substrates, untreated DDGS and waste-paper. Concentrations of total fermentation products (ethanol+acetate+lactate) formed by co-cultures were in general significantly higher than those reached by single non-cellulolytic strains, indicating cellulose utilization by the co-cultures. On the other hand, the co-cultures produced significantly more ethanol (22 to $63 \mathrm{~mol} \%$ ) compared to the single cellulolytic strain DIB 004C (7 to $13 \mathrm{~mol} \%$ ). Concentrations of ethanol in co-cultures on different substrates were 2.0- to 8.2-times higher than the concentrations of ethanol produced by single cellulolytic strains and generally higher than the concentrations reached by single noncellulolytic strains (Table 2 and Additional file 1: Table S3). Therefore, the tested co-cultures fermented cellulose and lignocellulosic substrates better than single strains and formed significant amounts of ethanol.

To improve fermentation of cellulose to ethanol, we have investigated 11 different compositions of co-cultures employing isolated Caldicellulosiruptor and Thermoanaerobacter strains. Co-cultures of C. saccharolyticus DSM 8903 and T. mathranii DSM 11426 were used as a control.
The cultures were grown on $10 \mathrm{~g} / \mathrm{l}$ Avicel in flasks with shaking without $\mathrm{pH}$ control. All tested co-cultures displayed good growth on Avicel but differed in ethanol production. The best ethanol productivity was demonstrated by a co-culture of Caldicellulosiruptor DIB 087C and Thermoanaerobacter DIB 097X with ethanol comprising $34.8 \mathrm{~mol} \%$ of the total organic products (Figure 3A and B). This co-culture displayed significant increase of ethanol production compared to the monoculture of Caldicellulosiruptor DIB 087C (11.2 mol\% ethanol) (Figure 3A and $B)$ and showed higher ethanol production than the cocultures DIB 004C + DIB 004G (22.1 mol\%, Table 2), DIB 004C + DIB 097X (25.4 mol\%, Table 2) and other cocultures tested. Only low ethanol production from Avicel (14.7 mol\% ethanol) was achieved with a co-culture of $C$. saccharolyticus DSM 8903 and ethanologenic T. mathranii DSM 11426 (Figure 3C). The dependence of ethanol production levels on the composition of co-cultures suggests different interactions of the investigated cellulolytic and non-cellulolytic bacteria in each of the dual co-cultures.

\section{Growth of single cultures and co-cultures in fermentors with $\mathrm{pH}$ control}

All growth experiments described above were performed in Hungate tubes or flasks without $\mathrm{pH}$ control. Cultivations in fermentors with $\mathrm{pH}$ control were conducted with Caldicellulosiruptor DIB 004C, Thermoanaerobacter DIB 004G and co-cultures of DIB 004C + DIB 004G.

Surprisingly, Caldicellulosiruptor DIB 004C produced high amounts of ethanol in fermentors at a constant $\mathrm{pH}$ of 6.75: $29.9 \mathrm{mM}$ (35.3 $\mathrm{mol} \%)$ to $51.3 \mathrm{mM}(29.7 \mathrm{~mol} \%)$ on $20 \mathrm{~g} / \mathrm{l}$ Avicel; $53.0 \mathrm{mM}$ (31.6 mol\%) to $71.5 \mathrm{mM}(41.7 \mathrm{~mol}$ \%) on $100 \mathrm{~g} / \mathrm{l}$ Avicel; $76.2 \mathrm{mM}$ (64.2 mol\%) on $50 \mathrm{~g} / \mathrm{l} \mathrm{glu}-$ cose; $35.4 \mathrm{mM}$ (52.1 mol\%) on $100 \mathrm{~g} / \mathrm{l}$ xylan; $24.3 \mathrm{mM}$ (66.8 mol\%) on $20 \mathrm{~g} / \mathrm{l}$ of unwashed pretreated poplar. In addition, strain DIB 004C produced $12.5 \mathrm{mM}$ ethanol from Avicel upon cultivation in flasks on media containing $10 \mathrm{~g} / \mathrm{l}$

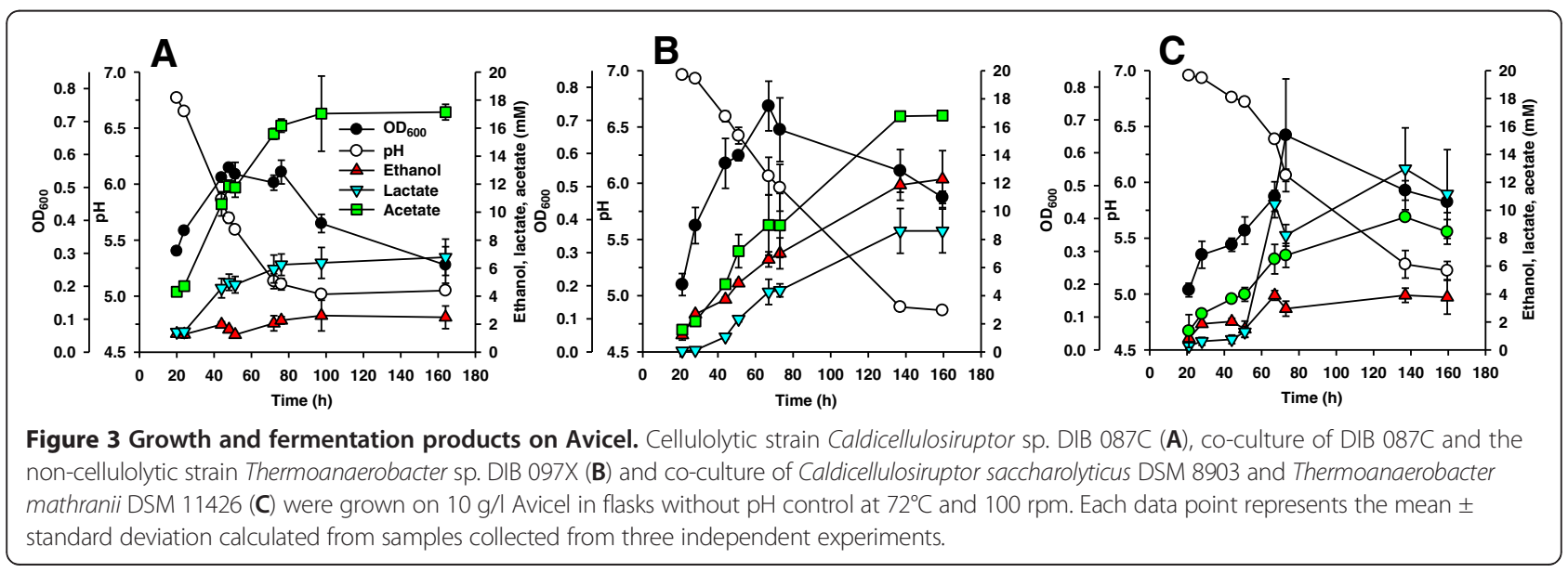


MOPS buffer for $\mathrm{pH}$ stabilization. Such ethanol productivity for a Caldicellulosiruptor strain is extraordinarily high, because so far formation of only traces of ethanol (up to $2 \mathrm{mM}$ ) was reported for known bacteria of the genus Caldicellulosiruptor grown without $\mathrm{pH}$ control $[15,17]$ or with $\mathrm{pH}$ control [16].

As expected, Thermoanaerobacter DIB 004G also produced high amounts of ethanol when $\mathrm{pH}$ was kept at 6.50 to 6.75: $131.8 \mathrm{mM}$ (51.9 mol\%) on $25 \mathrm{~g} / \mathrm{l}$ glucose; $163.5 \mathrm{mM}$ (59.8 mol\%) on $50 \mathrm{~g} / \mathrm{l}$ glucose; $50.7 \mathrm{mM}$ (75.4 mol\%) on $20 \mathrm{~g} / \mathrm{l}$ of unwashed pretreated poplar; $64.3 \mathrm{mM}(65.1 \mathrm{~mol} \%)$ to $120.1 \mathrm{mM}(55.0 \mathrm{~mol} \%)$ on $50 \mathrm{~g} / \mathrm{l}$ of unwashed pretreated poplar.

Cultivations in fermentors on Avicel (Figure 4) and pretreated unwashed poplar (Figure 5) with $\mathrm{pH}$ control at 6.75 confirmed the functionality of ethanologenic cocultures. In simultaneously performed fermentations on $20 \mathrm{~g} / \mathrm{l}$ Avicel, the monoculture of Caldicellulosiruptor DIB 004C produced $29.9 \mathrm{mM}$ ethanol and displayed an ethanol:acetate:lactate molar ratio of 1:1.1:0.7 corresponding to an ethanol productivity of $35.7 \mathrm{~mol} \%$ (Figure $4 \mathrm{~A}$ ). In contrast, the co-culture of Caldicellulosiruptor DIB 004C and Thermoanaerobacter DIB 004G produced $72.5 \mathrm{mM}$ ethanol as the main fermentation product with an ethanol: acetate:lactate molar ratio of 1:0.5:0.6 and an ethanol yield of $50.0 \mathrm{~mol} \%$. Therefore, ethanol production by this coculture increased 2.4 times compared to the strain DIB 004C alone (Figure 4B).

In simultaneously performed fermentations on $20 \mathrm{~g} / \mathrm{l}$ of unwashed pretreated poplar, ethanol was the main fermentation product with the monoculture of Caldicellulosiruptor DIB 004C (Figure 5A) as well as with the co-culture of Caldicellulosiruptor DIB 004C and Thermoanaerobacter DIB 004G (Figure 5B). The single culture DIB 004C produced $24.3 \mathrm{mM}$ ethanol $(66.8 \mathrm{~mol} \%)$ and $36.4 \mathrm{mM}$ of total fermentation products (ethanol+acetate+lactate) (Figure 5A). The co-culture of DIB 004C+DIB 004G produced $34.8 \mathrm{mM}$ ethanol $(50.9 \mathrm{~mol} \%)$ and $68.4 \mathrm{mM}$ of total fermentation products. In the first $40 \mathrm{~h}$ of growth ethanol was apparently produced by Thermoanaerobacter DIB 004G from free sugars present in pretreated poplar. During further growth acetate and small amounts of ethanol and lactate were produced by the co-culture from insoluble carbohydrates (Figure 5B).

Raw poplar used for production of pretreated material contained $42.4 \%$ glucan, $11.6 \%$ xylan, $1.8 \%$ galactan, $2.2 \%$ arabinan, $2.6 \%$ mannan, $5.4 \%$ acid-soluble lignin, $25.0 \%$ acid-insoluble lignin, and $0.5 \%$ lignin ash, as determined by standard laboratory methods [24]. Although we did not determine the composition of unwashed pretreated poplar, sulfurous acid steam explosion pretreatment of poplar usually results in insignificant loss of approx. $4 \%$ of solubilized sugars [25]. Neglecting this loss, the medium with $20 \mathrm{~g} / \mathrm{l}$ of unwashed pretreated poplar contained at most $52.3 \mathrm{mM}$ glucose, $17.6 \mathrm{mM}$ xylose, $2.2 \mathrm{mM}$ galactose, $3.3 \mathrm{mM}$ arabinose and $3.2 \mathrm{mM}$ mannose equivalents. Assuming a theoretical yield of $2.0 \mathrm{~mol}$ of ethanol+acetate +lactate per mol of C6 sugars and $1.67 \mathrm{~mol}$ of ethanol +acetate+lactate per mol of C5 sugars, formation of 150.3 $\mathrm{mM}$ ethanol+acetate+lactate could be expected from complete fermentation of carbohydrates in the medium containing $20 \mathrm{~g} / \mathrm{l}$ of employed pretreated poplar. Therefore, $24.2 \%$ and $45.5 \%$ of fermentable carbohydrates in unwashed pretreated poplar were utilized within the time frame of fermentations by the single strain DIB 004C and the co-culture of DIB 004C+DIB 004G, respectively.

\section{Fermentation balances}

The fermentation balances on glucose $(10 \mathrm{~g} / \mathrm{l})$, Avicel $(10 \mathrm{~g} / \mathrm{l})$, washed pretreated poplar $(6.05 \mathrm{~g} / \mathrm{l})$ and washed pretreated miscanthus $(6.09 \mathrm{~g} / \mathrm{l})$ for Caldicellulosiruptor sp. DIB 004C, Thermoanaerobacter sp. DIB 097X and a co-culture of DIB 004C + DIB 097X grown to the stationary phase in flasks without $\mathrm{pH}$ control revealed carbon and electron recoveries close to 100\% (Table 3). Only ethanol, acetate, lactate, $\mathrm{CO}_{2}$ and $\mathrm{H}_{2}$ were found as fermentation products. Based on composition of the washed pretreated substrates (Table 3), utilization of
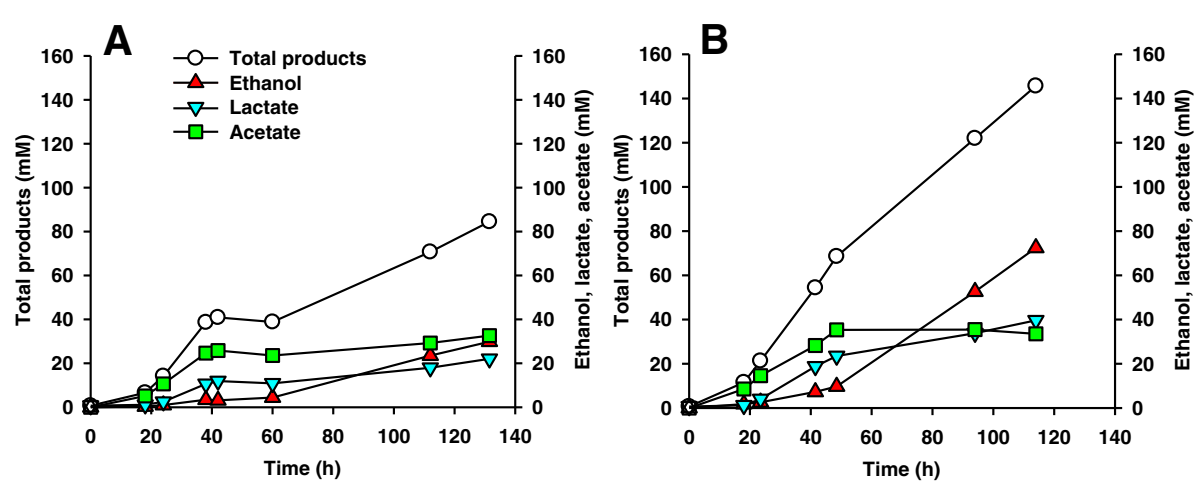

Figure 4 Fermentation products on Avicel in fermentors. Cellulolytic strain Caldicellulosiruptor sp. DIB 004C (A) and a co-culture of DIB 004C and of the non-cellulolytic strain Thermoanaerobacter sp. DIB 004G (B) were grown on $20 \mathrm{~g} / \mathrm{l}$ Avicel in fermentors at $72^{\circ} \mathrm{C}$ with pH stabilized at 6.75 . 

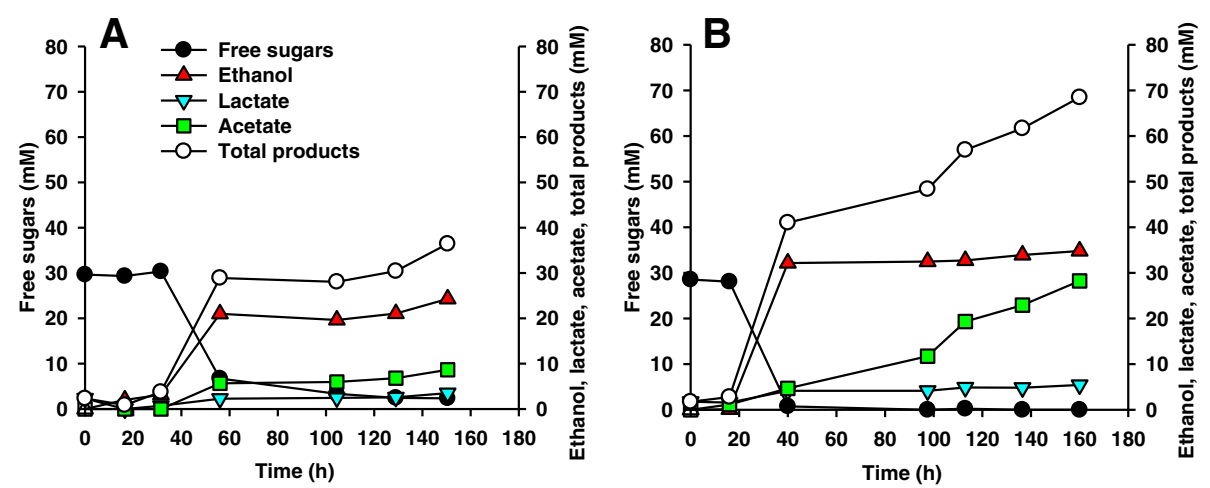

Figure 5 Fermentation products on pretreated poplar in fermentors. Cellulolytic strain Caldicellulosiruptor sp. DIB 004C (A) and a co-culture of DIB 004C and of the non-cellulolytic strain Thermoanaerobacter sp. DIB 004G (B) were grown on $20 \mathrm{~g} / \mathrm{l}$ (dry mass) of steam explosion pretreated poplar wood in fermentors at $72^{\circ} \mathrm{C}$ with pH stabilized at 6.75 .

fermentable carbohydrates reached $52 \%$ and $57 \%$ for the co-culture grown on poplar and miscanthus, respectively. It corresponded to a conversion of $30 \%$ and $33 \%$ of the biomass dry weight, respectively.

\section{Discussion}

The objective of this study was to isolate extremely thermophilic bacteria suitable for a single-step conversion of lignocellulosic biomass to ethanol at temperatures $>70^{\circ} \mathrm{C}$. Cellulolytic ethanologenic enrichments growing at $72^{\circ} \mathrm{C}$ and producing ethanol as the main fermentation product from crystalline cellulose and pretreated poplar wood were obtained from various environmental samples collected in Germany (Additional file 1: Table S1). From these enrichments seven cellulolytic strains of the genus Caldicellulosiruptor (Figure 1) and eight non-cellulolytic strains of the genus Thermoanaerobacter (Figure 2) were isolated, capable of growing at $72^{\circ} \mathrm{C}$.

All Caldicellulosiruptor strains were capable of fermenting crystalline cellulose, xylan, as well as glucose and xylose, making them suitable for the hydrolysis and fermentation of lignocellulosic substrates. All Thermoanaerobacter strains fermented glucose and xylose and five strains fermented xylan. Fermentation products of all Caldicellulosiruptor and Thermoanaerobacter strains included ethanol, lactate, acetate, $\mathrm{H}_{2}$ and $\mathrm{CO}_{2}$.

When Caldicellulosiruptor strains were grown in tubes or flasks without $\mathrm{pH}$ control on cellulose, cellobiose, glucose, xylan or xylose, $1-5 \mathrm{mM}$ of ethanol was accumulating in the fermentation (Table 1 and Additional file 1: Table S2). Surprisingly, the strain Caldicellulosiruptor DIB 004C produced $12.5 \mathrm{mM}$ ethanol from Avicel in flasks with MOPS buffer for $\mathrm{pH}$ stabilization. Ethanol concentrations of $71.5 \mathrm{mM}(3.3 \mathrm{~g} / \mathrm{l})$ and $76.2 \mathrm{mM}(3.5 \mathrm{~g} / \mathrm{l})$ were obtained when Caldicellulosiruptor DIB 004C was grown on Avicel and glucose, respectively, in $\mathrm{pH}-$ controlled fermentors, ethanol being the main product in some fermentation runs. In contrast, all know bacteria of the genus Caldicellulosiruptor produced only traces or low concentrations (up to $2 \mathrm{mM}$ ) of ethanol in fermentations performed with $\mathrm{pH}$ control [16] or without $\mathrm{pH}$ control $[17,18]$.

The high ethanol concentrations reported were obtained with the wild-type strain Caldicellulosiruptor DIB 004C grown on non-optimized medium under non-optimized cultivation conditions. These values are similar to ethanol levels reported for the most of wild-type strains of the thermophilic cellulolytic bacterium $C$. thermocellum, an extensively researched candidate for thermophilic CBP: strain ATCC 27405 in fermentor, $86.8 \mathrm{mM}$ (4 g/l) ethanol [11]; strain LQRI in flasks, $31.2 \mathrm{mM}(1.4 \mathrm{~g} / \mathrm{l})$ ethanol [13]; strain DSM 1313 in flasks, $28.2 \mathrm{mM}(1.3 \mathrm{~g} / \mathrm{l})$ ethanol [3,8]. An exception is the ethanol hyper-producing $C$. thermocellum wild-type strain I-1-B. The strain produced from cellulose $86.8 \mathrm{mM}(4 \mathrm{~g} / \mathrm{l})$ of ethanol in flasks on optimized medium with $14 \mathrm{~g} / \mathrm{l}$ yeast extract after 168 hours of fermentation [26] and $512 \mathrm{mM}$ (23.6 g/l) of ethanol in fermentors on optimized medium under optimized fermentation conditions after $156 \mathrm{~h}$ [27].

Ethanol was the main fermentation product of five isolated Thermoanaerobacter strains grown without $\mathrm{pH}$ control on cellobiose, glucose, xylan or xylose. The ethanol concentrations obtained were higher than those with the well known ethanologenic bacterium $T$. mathranii [20] which was used as a control (Table 1 and Additional file 1: Table S2). Up to $164 \mathrm{mM}$ ethanol was accumulated when Thermoanaerobacter sp. DIB 004G was grown on glucose with $\mathrm{pH}$ control. In this respect the isolated Thermoanaerobacter sp. strains were comparable to ethanologenic bacteria of the genus Thermoanaerobacter producing ethanol as the main fermentation product, e.g. T. mathranii subsp. mathranii str. A3 (DSM 11426) capable of producing $20 \mathrm{mM}$ ethanol from xylose [20], $T$. ethanolicus JW 200 (ATCC 31550) producing $78 \mathrm{mM}$ 
Table 3 Fermentation balances of carbohydrates by Caldicellulosiruptor sp. str. DIB 004C, Thermoanaerobacter sp. strain DIB 097X and co-cultures of the strains DIB 004C and DIB 097X on glucose, Avicel, washed pretreated poplar and washed pretreated miscanthus

\begin{tabular}{|c|c|c|c|c|c|c|c|c|c|c|c|c|c|c|c|c|c|}
\hline \multicolumn{18}{|c|}{ Growth on glucose } \\
\hline \multirow[t]{2}{*}{ Culture } & $\begin{array}{c}\text { Glucose } \\
\text { initial }\end{array}$ & $\begin{array}{c}\text { Glucose } \\
\text { consumed }\end{array}$ & Ethanol & Acetate & Lactate & $\mathrm{CO}_{2}$ & $\mathrm{H}_{2}$ & $\begin{array}{l}\text { Cell dry } \\
\text { weight }\end{array}$ & $\begin{array}{l}\text { Cell dry } \\
\text { weight }\end{array}$ & $\begin{array}{l}\text { Carbon in } \\
\text { consumed } \\
\text { glucose }\end{array}$ & $\begin{array}{l}\text { Carbon found } \\
\text { in products } \\
\text { and cells }\end{array}$ & $\begin{array}{l}\text { Carbon } \\
\text { recovery }\end{array}$ & $\begin{array}{l}\text { Electron } \\
\text { recovery }\end{array}$ & & & & \\
\hline & $\mathrm{mM}$ & $\mathrm{mM}$ & $\mathrm{mM}$ & $\mathrm{mM}$ & $\mathrm{mM}$ & $\mathrm{mM}$ & $\mathrm{mM}$ & $\begin{array}{c}\mathrm{mM} \\
\text { carbon }\end{array}$ & $g / l$ & $\mathrm{mM}$ & $\mathrm{mM}$ & $\%$ & $\%$ & & & & \\
\hline $\begin{array}{l}\text { Strain } \\
\text { DIB 004C }\end{array}$ & 55.51 & $30.6 \pm 2.8$ & $5.5 \pm 1.0$ & $21.9 \pm 2.6$ & $35.3 \pm 5.5$ & $8.8 \pm 7.4$ & $20.8 \pm 12.1$ & $9.7 \pm 1.9$ & $0.25 \pm 0.05$ & $183.8 \pm 16.9$ & $179.3 \pm 20.2$ & $98.9 \pm 18.2$ & $103.8 \pm 18.3$ & & & & \\
\hline $\begin{array}{c}\text { Strain } \\
\text { DIB 097X }\end{array}$ & 55.51 & $55.4 \pm 0.4$ & $53.1 \pm 7.6$ & $5.3 \pm 0.6$ & $55.6 \pm 4.9$ & $9.5 \pm 13.3$ & $2.4 \pm 1.3$ & $14.4 \pm 0.1$ & $0.37 \pm 0.00$ & $332.0 \pm 2.2$ & $307.4 \pm 29.5$ & $92.5 \pm 8.5$ & $107.9 \pm 10.7$ & & & & \\
\hline \multicolumn{18}{|c|}{ Growth on Avicel } \\
\hline \multirow[t]{2}{*}{ Culture } & $\begin{array}{l}\text { Avicel } \\
\text { initial }\end{array}$ & Avicel final & $\begin{array}{c}\text { Avicel } \\
\text { consumed }\end{array}$ & $\begin{array}{l}\text { Glucose } \\
\text { equivalents } \\
\text { initial }\end{array}$ & $\begin{array}{l}\text { Glucose } \\
\text { equivalents } \\
\text { consumed }\end{array}$ & Ethanol & Acetate & Lactate & $\mathrm{CO}_{2}$ & $\mathrm{H}_{2}$ & $\begin{array}{l}\text { Cell dry } \\
\text { weight }\end{array}$ & $\begin{array}{l}\text { Cell dry } \\
\text { weight }\end{array}$ & $\begin{array}{l}\text { Carbon in } \\
\text { consumed } \\
\text { glucose } \\
\text { equivalents }\end{array}$ & $\begin{array}{l}\text { Carbon found } \\
\text { in products } \\
\text { and cells }\end{array}$ & $\begin{array}{l}\text { Carbon } \\
\text { recovery }\end{array}$ & $\begin{array}{l}\text { Electron } \\
\text { recovery }\end{array}$ & $\begin{array}{c}\text { Consumption } \\
\text { of cellulose in } \\
\text { Avicel (100\% } \\
=61,7 \mathrm{mM} \\
\text { glucose } \\
\text { equivalents } \\
\text { consumed) }\end{array}$ \\
\hline & $g / l$ & $g / l$ & $g / l$ & $\mathrm{mM}$ & $\mathrm{mM}$ & $\mathrm{mM}$ & $\mathrm{mM}$ & $\mathrm{mM}$ & $\mathrm{mM}$ & $\mathrm{mM}$ & mM carbon & $g / l$ & $\mathrm{mM}$ & $\mathrm{mM}$ & $\%$ & $\%$ & $\%$ \\
\hline $\begin{array}{l}\text { Strain DIB } \\
004 C\end{array}$ & 10.00 & $5.88 \pm 0.02$ & $4.12 \pm 0.02$ & 61.68 & $25.4 \pm 0.1$ & $4.8 \pm 0.9$ & $11.6 \pm 2.1$ & $30.4 \pm 4.8$ & $9.1 \pm 6.3$ & $10 \pm 3.4$ & $9.3 \pm 1.3$ & $0.24 \pm 0.03$ & $152.6 \pm 0.6$ & $142.3 \pm 17.6$ & $93.2 \pm 11.5$ & $103.0 \pm 10.3$ & $41.2 \pm 0.2$ \\
\hline $\begin{array}{c}\text { Strain DIB } \\
004 C+ \\
\text { strain DIB } \\
097 X \\
\end{array}$ & 10.00 & $6.34 \pm 0.02$ & $3.66 \pm 0.02$ & 61.68 & $22.6 \pm 0.1$ & $6.2 \pm 0.4$ & $10.3 \pm 1.9$ & $25.7 \pm 3.8$ & $12.6 \pm 3.6$ & $9.2 \pm 2.4$ & $7.5 \pm 1.1$ & $0.19 \pm 0.03$ & $135.4 \pm 0.6$ & $130.1 \pm 14.7$ & $96.1 \pm 10.8$ & $105.0 \pm 2.6$ & $36.6 \pm 0.2$ \\
\hline \multicolumn{18}{|c|}{ Growth on washed pretreated poplar } \\
\hline \multirow[t]{2}{*}{$\begin{array}{l}\text { Culture } \\
\text {. }\end{array}$} & $\begin{array}{l}\text { Poplar } \\
\text { initial }\end{array}$ & Poplar final & $\begin{array}{c}\text { Poplar } \\
\text { consumed }\end{array}$ & $\begin{array}{c}\text { Glucose } \\
\text { equivalents } \\
\text { initial }\end{array}$ & $\begin{array}{l}\text { Glucose } \\
\text { equivalents } \\
\text { consumed }\end{array}$ & Ethanol & Acetate & Lactate & $\mathrm{CO}_{2}$ & $\mathrm{H}_{2}$ & $\begin{array}{l}\text { Cell dry } \\
\text { weight }\end{array}$ & $\begin{array}{l}\text { Cell dry } \\
\text { weight }\end{array}$ & $\begin{array}{l}\text { Carbon in } \\
\text { consumed } \\
\text { glucose } \\
\text { equivalents }\end{array}$ & $\begin{array}{l}\text { Carbon found } \\
\text { in products } \\
\text { and cells }\end{array}$ & $\begin{array}{l}\text { Carbon } \\
\text { recovery }\end{array}$ & $\begin{array}{l}\text { Electron } \\
\text { recovery }\end{array}$ & $\begin{array}{c}\text { Consumption } \\
\text { of cellulose in } \\
\text { poplar ( } 100 \% \\
=21.7 \mathrm{mM} \\
\text { glucose } \\
\text { equivalents } \\
\text { consumed) }\end{array}$ \\
\hline & $g / l$ & $g / l$ & $g / 1$ & $\mathrm{mM}$ & $\mathrm{mM}$ & $\mathrm{mM}$ & $\mathrm{mM}$ & $\mathrm{mM}$ & $\mathrm{mM}$ & $\mathrm{mM}$ & mM carbon & $g / l$ & $\mathrm{mM}$ & $\mathrm{mM}$ & $\%$ & $\%$ & $\%$ \\
\hline $\begin{array}{l}\text { Strain DIB } \\
004 C\end{array}$ & 6.05 & $4.80 \pm 0.43$ & $1.48 \pm 0.76$ & 21.70 & $9.1 \pm 4.7$ & $0.2 \pm 0.2$ & $13.3 \pm 2.2$ & $7.5 \pm 0.6$ & $5.1 \pm 4.3$ & $8.1 \pm 3.1$ & $11.6 \pm 0.0$ & $0.30 \pm 0.0$ & $54.7 \pm 28.0$ & $65.9 \pm 6.6$ & $120.6 \pm 12.0$ & $137.8 \pm 58.1$ & $42.0 \pm 21.5$ \\
\hline $\begin{array}{c}\text { Strain DIB } \\
004 C+ \\
\text { strain DIB } \\
097 X\end{array}$ & 6.05 & $4.21 \pm 0.57$ & $1.84 \pm 0.57$ & 21.70 & $11.3 \pm 3.5$ & $3.2 \pm 1.9$ & $13.2 \pm 3.3$ & $6.3 \pm 4.0$ & $5.7 \pm 5.0$ & $11.0 \pm 4.7$ & $10.2 \pm 0.1$ & $0.26 \pm 0.0$ & $68.0 \pm 21.0$ & $67.5 \pm 16.8$ & $99.3 \pm 24.8$ & $106.5 \pm 24.4$ & $52.2 \pm 16.2$ \\
\hline
\end{tabular}


Table 3 Fermentation balances of carbohydrates by Caldicellulosiruptor sp. str. DIB 004C, Thermoanaerobacter sp. strain DIB 097X and co-cultures of the strains DIB 004C and DIB 097X on glucose, Avicel, washed pretreated poplar and washed pretreated miscanthus (Continued)

\begin{tabular}{|c|c|c|c|c|c|c|c|c|c|c|c|c|c|c|c|c|c|}
\hline Culture & $\begin{array}{l}\text { Miscanthus } \\
\text { initial }\end{array}$ & $\begin{array}{l}\text { Miscanthus } \\
\text { final }\end{array}$ & $\begin{array}{l}\text { Miscanthus } \\
\text { consumed }\end{array}$ & $\begin{array}{l}\text { Glucose } \\
\text { equivalents } \\
\text { initial }\end{array}$ & $\begin{array}{l}\text { Glucose } \\
\text { equivalents } \\
\text { consumed }\end{array}$ & Ethanol & Acetate & Lactate & $\mathrm{CO}_{2}$ & $\mathrm{H}_{2}$ & $\begin{array}{l}\text { Cell dry } \\
\text { weight }\end{array}$ & $\begin{array}{l}\text { Cell dry } \\
\text { weight }\end{array}$ & $\begin{array}{l}\text { Carbon in } \\
\text { consumed } \\
\text { glucose } \\
\text { equivalents }\end{array}$ & $\begin{array}{l}\text { Carbon found } \\
\text { in products } \\
\text { and cells }\end{array}$ & $\begin{array}{l}\text { Carbon } \\
\text { recovery }\end{array}$ & $\begin{array}{l}\text { Electron } \\
\text { recovery }\end{array}$ & $\begin{array}{c}\text { Consumption } \\
\text { of cellulose } \\
\text { in miscanthus } \\
\text { (100\% }=21.8 \\
\mathrm{mM} \text { glucose } \\
\text { equivalents } \\
\text { consumed) }\end{array}$ \\
\hline & $g / l$ & $g / l$ & $g / 1$ & $\mathrm{mM}$ & $\mathrm{mM}$ & $\mathrm{mM}$ & $\mathrm{mM}$ & $\mathrm{mM}$ & $\mathrm{mM}$ & $\mathrm{mM}$ & mM carbon & $\mathrm{g} / \mathrm{l}$ & $\mathrm{mM}$ & $\mathrm{mM}$ & $\%$ & $\%$ & $\%$ \\
\hline $\begin{array}{c}\text { Strain DIB } \\
004 C\end{array}$ & 6.09 & $4.14 \pm 0.03$ & $1.95 \pm 0.03$ & 21.80 & $12.0 \pm 0.2$ & $2.7 \pm 2.3$ & $11.6 \pm 1.9$ & $6.3 \pm 1.3$ & $4.4 \pm 4.7$ & $7.2 \pm 5.7$ & $8.9 \pm 1.7$ & $0.23 \pm 0.04$ & $72.1 \pm 1.2$ & $64.6 \pm 10.8$ & $89.6 \pm 15.0$ & $94.6 \pm 17.8$ & $55.1 \pm 0.9$ \\
\hline $\begin{array}{c}\text { Strain DIB } \\
004 C+ \\
\text { strain DIB } \\
097 X\end{array}$ & 6.09 & $4.08 \pm 0.08$ & $2.01 \pm 0.08$ & 21.80 & $12.4 \pm 0.5$ & $5.2 \pm 1.8$ & $13.0 \pm 1.5$ & $5.5 \pm 1.0$ & $4.0 \pm 1.9$ & $9.8 \pm 1.9$ & $8.4 \pm 2.1$ & $0.22 \pm 0.05$ & $74.5 \pm 2.9$ & $69.2 \pm 4.6$ & $92.9 \pm 6.1$ & $102.3 \pm 6.4$ & $57.0 \pm 2.2$ \\
\hline
\end{tabular}

Fermentations were performed in $240 \mathrm{ml}$ flasks containing $100 \mathrm{ml}$ cultures with glucose, Avicel, washed pretreated poplar or washed pretreated miscanthus as substrates. Cultures were incubated at $72^{\circ} \mathrm{C}$ and $100 \mathrm{rpm}$ for $41 \mathrm{~h}$ (glucose), $64 \mathrm{~h}$ (Avicel) and $400 \mathrm{~h}$ (poplar and miscanthus). Initial substrate concentrations were: $10 \mathrm{~g} / \mathrm{l}(55.5 \mathrm{mM}$ ) of glucose; $10 \mathrm{~g} / \mathrm{l}$ (61.7 mM glucose equivalents) of Avicel; $6.05 \mathrm{~g} / \mathrm{l} \mathrm{dry} \mathrm{material} \mathrm{(21.7} \mathrm{mM}$ glucose equivalents, $00.0 \mathrm{mM}$ xylose equivalents, $0.1 \mathrm{mM}$ galactose equivalents) of washed poplar; $6.09 \mathrm{~g} / \mathrm{l}$ dry material (21.8 mM glucose equivalents, $1.1 \mathrm{mM}$ xylose equivalents, $0.0 \mathrm{mM}$ galactose equivalents) of washed miscanthus. Concentrations of carbohydrates in washed pretreated poplar and miscanthus were determined according to the standard procedure from NREL [24].

Carbon balances presented in Table 3 were determined by measurements of initial and final carbohydrate concentrations and final carbon-containing end products, including cell dry weight by using the general empirical formula for cell composition of $\mathrm{CH}_{2} \mathrm{~N}_{0.25} \mathrm{O}_{0.5}$ [19,32]. For washed pretreated poplar and miscanthus the loss of weight was attributed to the consumption of cellulose, since no xylose was detected in these substrates. Carbon contained in yeast extract and extracellular protein was not included in the carbon recovery. Carbon and electron balances were calculated as described [32].

Data represent averages of the results of six replicate fermentation experiments. 
from glucose [28] and T. thermohydrosulfuricus strain E100-69 (DSM 567) producing 29 mM from glucose [29].

Cellulolytic strains DIB 004C and DIB 101C grew well on insoluble carbohydrates (mainly cellulose) contained in washed pretreated lignocellulosic substrates. At low substrate concentrations, strain DIB 004C utilized up to $89.1 \%$ of insoluble cellulose and hemicellulose present in washed pretreated poplar (Table 2) and up to $97 \%$ of insoluble cellulose and hemicellulose present in washed pretreated spruce, corn cobs and corn stalks (Additional file 1: Table S4). The ability of novel Caldicellulosiruptor strains to utilize all major carbohydrates from lignocellulosic materials can be attributed to the presence of a large set of extracellular glycoside hydrolases, similar to those found in C. saccharolyticus [30,31] and C. bescii [32]. At high concentrations of Avicel or pretreated lignocellulosic materials the carbohydrate consumption by cellulolytic strains was not complete. In fermentations without $\mathrm{pH}$ control this can be attributed to acidification of the media to $\mathrm{pH}$ below 5.0. In $\mathrm{pH}-$ controlled fermentations osmotic pressure was shown to affect growth of $T$. thermosaccharolyticum [33] and $C$. saccharolyticus [34].

Similar to C. bescii [32], the novel Caldicellulosiruptor strains displayed planktonic growth on Avicel and lignocellulosic substrates. Microscopic examinations revealed that most of the cells were not attached to the substrate particles. This is in agreement with formation of extracellular glycoside hydrolases and enabled to follow growth via cell density measurements.

High ethanol production from cellulose and pretreated poplar demonstrated for a number of our extremely thermophilic enrichment cultures could be explained by the synergistic functioning of natural co-cultures of cellulolytic (Caldicellulosiruptor) and non-cellulolytic (Thermoanaerobacter) bacteria isolated from these enrichments. Fermentations using co-cultures of thermophilic cellulolytic and non-cellulolytic bacteria represent a promising approach for CBP technology and have been investigated at $50^{\circ} \mathrm{C}-60^{\circ} \mathrm{C}$ with co-cultures of thermophilic Clostridium thermocellum and different species of Thermoanaerobacter or Thermoanaerobacterium $[7,8$, 10-13]. In these co-cultures, faster cellulose degradation and increased ethanol production was observed, explained by removal of free sugars, produced from cellulose by C. thermocellum, by the non-cellulolytic bacteria [13].

De-novo constructed dual CaldicellulosiruptorThermoanaerobacter co-cultures revealed up to 8-fold increased ethanol yields compared to the monocultures of Caldicellulosiruptor strains (Table 2 and Additional file 1: Table S3). Ethanol production by co-cultures was strongly dependent on their composition. From 11 different compositions of dual co-cultures grown on Avicel in flasks, the highest ethanol production was obtained with a co-culture comprising Caldicellulosiruptor DIB 087C and Thermoanaerobacter DIB 097X: $13.8 \mathrm{mM}$ ethanol and $34.8 \mathrm{~mol} \%$ of ethanol fraction within the total organic products (Figure 3). In a control experiment, the co-culture of C. saccharolyticus DSM 8903 and Thermoanaerobacter mathranii DSM 11426 displayed the lowest ethanol yield from all co-cultures tested: $3.3 \mathrm{mM}$ of ethanol and $14.7 \mathrm{~mol} \%$ of ethanol fraction within the total organic products (Figure 3). The functionality of cocultures was also confirmed in $\mathrm{pH}$-controlled fermentations. The ethanol concentration on Avicel in the coculture of DIB 004C+DIB 004G increased more than 2fold compared to the monoculture of DIB 004C (Figure 4). Growth of the same cultures on unwashed pretreated poplar revealed a 1.4-fold increase in ethanol levels for the coculture (Figure 5). Therefore, the established co-cultures operated similar to the original ethanologenic enrichments, a synergistic effect of the bacteria in co-cultures being apparent.

Although the amounts of ethanol produced by novel cellulolytic strains and co-cultures are relatively high compared to other Caldicellulosiruptor and Thermoanaerobacter species, we are currently working on the optimization of strain performance to maximize ethanol levels. Product profiles as well as conversion of pretreated lignocellulosic materials are addressed by classical strain improvement approaches, targeted genetic engineering of the organisms and improved pretreatment methods. The feasibility of genetic modifications of the novel Caldicellulosiruptor and Thermoanaerobacter strains is supported by the recent progress in the development of genetic tools for T. saccharolyticum [19] and C. thermocellum [8] in the projects to produce high ethanol yields and the success in genetic manipulation of $C$. bescii $[35,36]$.

\section{Conclusions}

Here we have shown for the first time that the developed extremely thermophilic co-cultures of Caldicellulosiruptor and Thermoanaerobacter are capable of efficiently converting C6- and C5-sugars from cellulose and various pretreated lignocellulosic materials into ethanol, lactate and acetate, ethanol being the major fermentation product. No external enzyme additions were required since the appropriate cellulolytic and hemicellulolytic enzymes were provided by cellulolytic/xylanolytic Caldicellulosiruptor sp. bacteria and by non-cellulolytic/xylanolytic Thermoanaerobacter sp. bacteria. Therefore, these co-cultures are promising for direct fermentation of lignocellulosic biomass to ethanol in a CBP process with operating temperatures above $70^{\circ} \mathrm{C}$.

In particular the newly identified Caldicellulosiruptor strain DIB 004C provides an unmatched combination of efficient hydrolysis of $\mathrm{C} 5$ - and C6-sugar polymers derived from lignocellulose, high ethanol production 
levels and conversion of both C5 and C6 sugars. Therefore, the strain represents an ideal basis for the development of a high temperature lignocellulose to ethanol CBP, either with DIB 004C alone or in a co-culture with one of the newly identified Thermoanaerobacter strains.

\section{Methods}

\section{Bacterial strains}

The new isolates of extremely thermophilic anaerobic cellulolytic and saccharolytic non-cellulolytic bacteria were obtained from different soil, mud and compost samples collected in the Rhineland and Cologne area in North Rhine-Westphalia, Germany. Caldicelulosiruptor saccharolyticus DSM 8903 and Thermoanaerobacter mathranii subsp. mathranii DSM 11426 were purchased from the DSMZ collection (Deutsche Sammlung von Mikroorganismen und Zellkulturen $\mathrm{GmbH}$ ).

\section{Enrichment, isolation and cultivation}

A prereduced medium was used for enrichment cultures and cultivation of isolated strains. The medium contained (per liter deionized water): $\mathrm{K}_{2} \mathrm{HPO}_{4}, 1.5$ g; $\mathrm{KH}_{2} \mathrm{PO}_{4}, 3 \mathrm{~g} ; \mathrm{MgSO}_{4} \times 7 \mathrm{H}_{2} \mathrm{O}, 0.3 \mathrm{~g} ; \mathrm{CaCO}_{3} \times 2 \mathrm{H}_{2} \mathrm{O}$, 0.05 g; $\mathrm{NH}_{4} \mathrm{Cl}, 1.0 \mathrm{~g} ; \mathrm{NaCl}, 0.5 \mathrm{~g} ; \mathrm{NaHCO}_{3}, 0.5 \mathrm{~g} ; \mathrm{NiCl}_{2}$ $\times 6 \mathrm{H}_{2} \mathrm{O}, 2 \mathrm{mg} ; \mathrm{FeSO}_{4} \times 7 \mathrm{H}_{2} \mathrm{O}, 1 \mathrm{mg} ; \mathrm{NH}_{4} \mathrm{Fe}(\mathrm{III})$ citrate, $10 \mathrm{mg} ; \mathrm{MnSO}_{4} \times \mathrm{H}_{2} \mathrm{O}, 5 \mathrm{mg} ; \mathrm{CoCl}_{2} \times 6 \mathrm{H}_{2} \mathrm{O}$, $1 \mathrm{mg} ; \mathrm{ZnSO}_{4} \times 7 \mathrm{H}_{2} \mathrm{O}, 1 \mathrm{mg} ; \mathrm{CuSO}_{4} \times 5 \mathrm{H}_{2} \mathrm{O}, 0.1 \mathrm{mg}$; $\mathrm{H}_{3} \mathrm{BO}_{4}, 0.1 \mathrm{mg} ; \mathrm{Na}_{2} \mathrm{MoO}_{4} \times 2 \mathrm{H}_{2} \mathrm{O}, 0.1 \mathrm{mg} ; \mathrm{Na}_{2} \mathrm{SeO}_{3} \times$ $5 \mathrm{H}_{2} \mathrm{O}, 0.2 \mathrm{mg} ; \mathrm{Na}_{2} \mathrm{WoO}_{4} \times 2 \mathrm{H}_{2} \mathrm{O}, 0.1 \mathrm{mg}$; nicotinic acid, $2 \mathrm{mg}$; cyanocobalamin, $0.25 \mathrm{mg}$; p-aminobenzoic acid, $0.25 \mathrm{mg}$; calcium pantothenate, $0.25 \mathrm{mg}$; thiaminehydrochloride, $0.25 \mathrm{mg}$; riboflavin, $0.25 \mathrm{mg}$; lipoic acid, $0.25 \mathrm{mg}$; folic acid, $0.1 \mathrm{mg}$; biotin, $0.1 \mathrm{mg}$; pyridoxinehydrochloride, $0.1 \mathrm{mg}$; yeast extract (Difco), $0.5 \mathrm{~g}$; resazurin, $0.5 \mathrm{mg} ; \mathrm{Na}_{2} \mathrm{~S} \times 9 \mathrm{H}_{2} \mathrm{O}, 0.75 \mathrm{~g}$.

The medium was prepared under anaerobic conditions under $\mathrm{O}_{2}$-free $\mathrm{N}_{2}$ and $\mathrm{pH}$ was adjusted to 7.2. The medium was dispensed into flasks and Hungate tubes under $\mathrm{N}_{2}$ and autoclaved.

Enrichment medium was inoculated with collected samples and incubated at $72^{\circ} \mathrm{C}$ in $50 \mathrm{ml}$ flasks with 30 $\mathrm{ml}$ medium containing $4.3 \mathrm{~g} / \mathrm{l}$ of cellulose (strips of filter paper Whatman No.1) and $20 \mathrm{~g} / \mathrm{l}$ of untreated ground beech wood as substrate.

Cellulolytic strains were isolated by serial dilutions of single-cell colonies in Hungate roll tubes [37] with $30 \mathrm{~g} / \mathrm{l}$ agar and $5 \mathrm{~g} / \mathrm{l}$ acid-swollen amorphous cellulose. Noncellulolytic strains were isolated by repeated serial dilutions in liquid medium with $5 \mathrm{~g} / \mathrm{l}$ glucose.

Isolated strains were cultivated at $72^{\circ} \mathrm{C}$ in Hungate tubes or flasks with filter paper, microcrystalline cellulose (Avicel PH-101, Fluka), cellobiose, glucose, xylan from beech wood, xylose, washed or unwashed dilute sulfurous acid steam-explosion-pretreated lignocellulosic materials (poplar, spruce, miscanthus, wheat straw, whole corn plants, corn cobs, corn stalks, sugarcane bagasse, sweet sorghum, cotton stalks), dried distillers grains with solubles (DDGS), and waste paper as substrates. Hungate tubes were incubated without shaking. Flasks were incubated with shaking at $100 \mathrm{rpm}$.

Growth of bacteria was monitored by analysis of fermentation products and determination of optical density of the cultures $\left(\mathrm{OD}_{600}\right)$. For the separation of cells from insoluble substrates, samples were centrifuged in $2 \mathrm{ml}$ tubes for $20 \mathrm{~s}$ at $1.700 \mathrm{~g}$.

In experiments on fermentation balance $\mathrm{NaHCO}_{3}$ was omitted from the media and insoluble substrates were separated from cells by centrifugation of the cultures in $50 \mathrm{ml}$ tubes for $60 \mathrm{~s}$ at $1.700 \mathrm{~g}$. Cells were washed with $0.9 \% \mathrm{NaCl}$ and substrates were washed with distilled water. After centrifugation cells and substrates were dried at $90^{\circ} \mathrm{C}$ for $24 \mathrm{~h}$.

Lignocellulosic substrates were pretreated by acidic steam explosion applying $2 \%(\mathrm{w} / \mathrm{v})$ sulfurous acid at a temperature of $205^{\circ} \mathrm{C}$ for 5 min prior to sudden release of pressure. To obtain the insoluble carbohydrate fraction, pretreated substrates were washed three times with water at $72^{\circ} \mathrm{C}$. Substrates were suspended in distilled water (100 g dry mass $/ 5$ liter) and incubated for $16 \mathrm{~h}$ at $72^{\circ} \mathrm{C}$ with stirring. After filtration under vacuum, substrates were washed two times (each time for $2 \mathrm{~h}$ with stirring) with equal volumes of water at $72^{\circ} \mathrm{C}$. Washed substrates were removed by filtration, dried at $45^{\circ} \mathrm{C}$ for $66 \mathrm{~h}$ and used for growth experiments. Dry weight of washed and unwashed substrates was determined after drying at $105^{\circ} \mathrm{C}$ for $24 \mathrm{~h}$.

Composition of raw untreated substrates and washed pretreated substrates was determined according to the laboratory analytical procedure "Determination of structural carbohydrates and lignin in biomass" from National Renewable Energy Laboratory (NREL) [24].

Fermentations were carried out in 2-liter stirred vessel fermentors (Biostat B-DCU, B.Braun / Sartorius AG) with a working volume of 1.2 liter. All vessels were equipped with double jackets for temperature control, two Rushton-type stirrer blades and $\mathrm{pH}$-control loops. In order to maintain a constant pressure throughout the cultivation, vessels were additionally equipped with high-precision blow-off valves, controlling the pressure in the range of 1.3-1.5 bar. The medium as described above was supplemented with Avicel, pretreated poplar wood, xylan or glucose. The medium was set to $\mathrm{pH} 6.75$ by automatic addition of $\mathrm{NaOH}$ solution and this value maintained throughout the fermentation run. In order to remove oxygen from the medium, the fermentor vessel was flushed with nitrogen for $1 \mathrm{~h}$ at a rate of $1 \mathrm{l} / \mathrm{min}$; then $\mathrm{Na}_{2} \mathrm{~S} \times 9 \mathrm{H}_{2} \mathrm{O}$ was added as described above while gas flushing was stopped. Each fermentor was inoculated 
with $100 \mathrm{ml}$ of seed culture prepared as described above for cultivation of a single strain and with $50 \mathrm{ml}$ of each seed culture for co-cultivation of two strains. Cellulolytic seed cultures were grown on $10 \mathrm{~g} / \mathrm{l}$ Avicel. Non-cellulolytic seed cultures were grown on $5 \mathrm{~g} / \mathrm{l}$ glucose. A temperature of $72^{\circ} \mathrm{C}$ was maintained during the entire fermentation run.

\section{Genomic DNA isolation and 16S rRNA gene sequence analysis}

DNA from the isolated cultures was extracted using a peqGold Bacterial DNA kit (PEQLAB Biotechnologie $\mathrm{GmbH}$ ) or a MasterPure DNA Purification Kit (Biozym Scientific $\mathrm{GmbH}$ ). The DNA was then amplified by PCR employing a bacterial domain-specific primer set for $16 \mathrm{~S}$ rRNA, 27 forward and 1492 reverse [38], and KOD Hot Start DNA polymerase (Novagen). PCR was carried out according to protocol recommended for KOD Hot Start DNA polymerase by the manufacturer. PCR products were purified with a QIAquick PCR Purification kit (Qiagen) and sequenced.

The $16 \mathrm{~S}$ rRNA gene sequences were analyzed using nucleotide to nucleotide BLAST (BLASTN) at NCBI (http:// www.ncbi.nlm.nih.gov/blast/). Phylogenetic 16S rRNA gene analyses were performed by the neighbor-joining method [39] using the program Mega 4 [40].

\section{Analysis of fermentation products}

Organic fermentation products ethanol, lactate and acetate were analyzed on a Hitachi Lachrom Elite highperformance liquid chromatography (HPLC) system (Hitachi High Technologies). Metabolites were separated on a Rezex ROA $150 \times 4.6 \mathrm{~mm}$ column (Phenomenex) under isocratic temperature $\left(65^{\circ} \mathrm{C}\right)$ and flow $(0.8 \mathrm{ml} /$ min) conditions in $2.5 \mathrm{mM} \mathrm{H}_{2} \mathrm{SO}_{4}$ and then passed through a refractive index (RI) detector (Hitachi L-2490 ). Identification was performed by comparison of retention times with standards. $\mathrm{H}_{2}$ and $\mathrm{CO}_{2}$ were analyzed by gas chromatography with thermal conductivity detection. For analysis of $\mathrm{CO}_{2}$ the cultures in flasks were acidified with $\mathrm{HCl}$ to lower the $\mathrm{pH}$ below 1.4.

Carbon balances were determined by measurement of initial and final carbohydrate concentrations and final carbon-containing end products, including cell dry weight, using the general empirical formula for cell composition of $\mathrm{CH}_{2} \mathrm{~N}_{0.25} \mathrm{O}_{0.5}[19,41]$. For washed pretreated poplar and miscanthus the loss of weight was attributed to the consumption of cellulose, since no xylose was detected in these substrates. Carbon contained in yeast extract and extracellular protein was not included in the carbon recovery. Carbon and electron balances were calculated as described [41].

\section{Additional file}

Additional file 1: Table S1. Fermentation products of ethanologenic enrichment cultures. Table S2. Fermentation products of cellulolytic and non-cellulolytic strains isolated from ethanologenic enrichment cultures. Table S3. Fermentation products of Caldicellulosiruptor DIB004C alone and in co-cultures with Thermoanaerobacter DIB004G and DIB097X. Table S4. Fermentation products of Caldicellulosiruptor DIB004C and DIB101C on washed pretreated substrates.

\section{Abbreviations}

CBP: Consolidated bioprocessing; Avicel: Crystalline cellulose; DDGS: Dried distillers grains with solubles; MOPS: 3-Morpholinopropanesulfonic acid; NREL: National Renewable Energy Laboratory; PCR: Polymerase chain reaction; BLAST: Basic local alignment search tool; HPLC: High performance liquid chromatography; Rl: Refractive index.

\section{Competing interests}

All authors are current employees of Direvo Industrial Biotechnology $\mathrm{GmbH}$. Direvo actively develops processes for lignocellulose conversion to fuels and chemicals.

\section{Authors' contributions}

VS, OK and SC conceived the study and wrote the paper. VS and DF carried out the enrichment work and performed the isolation of cultures and the phylogenetic studies. VS, DF, SK and AS performed the fermentation experiments in flasks/tubes. MP and JS performed experiments in fermentors. AS and NL carried out the analysis of fermentation products. All authors read and approved the final manuscript.

\section{Acknowledgements}

We thank Guido Zacchi and Christian Roslander, Lund University, Sweden, for the preparation and analysis of pretreated materials.

Received: 17 July 2012 Accepted: 4 February 2013

Published: 28 February 2013

\section{References}

1. Mussatto SI, Dragone G, Guimarães PMR, Silva JPA, Carneiro LM, Roberto IC, Vicente A, Domingues L, Teixeira JA: Technological trends, global market, and challenges of bio-ethanol production. Biotechnol Adv 2010, 28:817-830.

2. Farrell AE, Plevin RJ, Turner BT, Jones AD, O'Hare M, Kammen DM: Ethanol can contribute to energy and environmental goals. Science 2006, 311:506-508.

3. Olson DG, McBride JE, Joe Shaw A, Lynd LR: Recent progress in consolidated bioprocessing. Curr Opin Biotechnol 2011, 23:1-10.

4. Klein-Marcuschamer D, Oleskowicz-Popiel P, Simmons BA, Blanch HW: The challenge of enzyme cost in the production of lignocellulosic biofuels. Biotechnol Bioeng 2012, 109:1083-1087.

5. Lynd LR, Weimer PJ, van ZyI WH, Pretorius IS: Microbial cellulose utilization: fundamentals and biotechnology. Microbiol Mol Biol Rev 2002, 66:506-577

6. La Grange DC, den Haan R, van Zyl WH: Engineering cellulolytic ability into bioprocessing organisms. Appl Microbiol Biotechnol 2010, 87:1195-1208.

7. Demain AL, Newcomb M, Wu JH: Cellulase, clostridia, and ethanol. Microbiol Mol Biol Rev 2005, 69:124-154.

8. Argyros DA, Tripathi SA, Barrett TF, Rogers SR, Feinberg LF, Olson DG, Foden JM, Miller BB, Lynd LR, Hogsett DA, Caiazza NC: High ethanol titers from cellulose by using metabolically engineered thermophilic, anaerobic microbes. Appl Environ Microbiol 2011, 77:8288-8294.

9. Taylor MP, Eley KL, Martin S, Tuffin MI, Burton SG, Cowan DA: Thermophilic ethanologenesis: future prospects for second-generation bioethanol production. Trends Biotechnol 2009, 27:398-405.

10. Venkateswaran S, Demain AL: The Clostridium thermocellum-Clostridium thermosaccharolyticum ethanol production process: nutritional studies and scale-down. Chem Eng Commun 1986, 45:53-60.

11. Wang DIC, Avgerinos GC, Biocic I, Wang S-D, Fang H-Y: Ethanol from cellulosic biomass. Phil Trans R Soc Lond 1983, B300:323-333.

12. He Q, Hemme $C L$, Jiang $H$, He Z, Zhou J: Mechanisms of enhanced cellulosic bioethanol fermentation by co-cultivation of Clostridium and Thermoanaerobacter spp. Bioresour Technol 2011, 102:9586-9592. 
13. Ng TK, Ben-Bassat A, Zeikus JG: Ethanol production by thermophilic bacteria: fermentation of cellulosic substrates by cocultures of Clostridium thermocellum and Clostridium thermohydrosulfuricum. Appl Environ Microbiol 1981, 41:1337-1343.

14. Wiegel J: Formation of ethanol by bacteria. A pledge for the use of extreme thermophilic anaerobic bacteria in industrial ethanol fermentation processes. Experientia 1980, 36:1434-1446.

15. Willquist K, Zeidan AA, van Niel EW: Physiological characteristics of the extreme thermophile Caldicellulosiruptor saccharolyticus: an efficient hydrogen cell factory. Microb Cell Fact 2010, 9:89.

16. Hamilton-Brehm SD, Mosher JJ, Vishnivetskaya T, Podar M, Carroll S, Allman S, Phelps TJ, Keller M, Elkins JG: Caldicellulosiruptor obsidiansis sp. nov., an anaerobic, extremely thermophilic, cellulolytic bacterium isolated from Obsidian Pool, Yellowstone National Park. Appl Environ Microbiol 2010, 76:1014-1020

17. Yang S-J, Kataeva I, Hamilton-Brehm SD, Engle NL, Tschaplinski TJ, Doeppke C, Davis M, Westpheling J, Adams MWW: Efficient degradation of lignocellulosic plant biomass, without pretreatment, by the thermophilic anaerobe "Anaerocellum thermophilum" DSM 6725. Appl Environ Microbiol 2009, 75:4762-4769.

18. Donnison AM, Brockelsby CM, Morgan HW, Daniel RM: The degradation of lignocellulosics by extremely thermophilic microorganisms. Biotechnol Bioeng 1989, 33:1495-1499.

19. Shaw AJ, Podkaminer KK, Desai SG, Bardsley JS, Rogers SR, Thorne PG, Hogsett DA, Lynd LR: Metabolic engineering of a thermophilic bacterium to produce ethanol at high yield. Proc Natl Acad Sci USA 2008, 105:13769-13774.

20. Larsen L, Nielsen P, Ahring BK: Thermoanaerobacter mathranii sp. nov., an ethanol-producing, extremely thermophilic anaerobic bacterium from a hot spring in Iceland. Arch Microbiol 1997, 168:114-119.

21. Lee $Y-E$, Jain MK, Lee C, Lowe SE, Zeikus JG: Taxonomic distinction of saccharolytic thermophilic anaerobes: description of Thermoanaerobacterium xylanolyticum gen. nov., sp. nov., and Thermoanaerobacterium saccharolyticum gen. nov., sp.nov.; reclassification of Thermoanaerobium brockii, Clostridium thermosulfurogenes, and Clostridium thermohydrosulfiricum E100-69 as Thermoanaerobacter brockii comb. nov., Thermoanaerobacterium thermosulfurigenes comb. nov., and Thermoanaerobacter thermohydrosulfuricus comb. nov., respectively; and transfer of Clostridium thermohydrosulfuricum 39E to Thermoanaerobacter ethanolicus. Int J Syst Bacteriol 1993, 43:41-51.

22. Klinke HB, Thomsen AB, Ahring BK: Inhibition of ethanol-producing yeast and bacteria by degradation products produced during pre-treatment of biomass. Appl Microbiol Biotechnol 2004, 66:10-26.

23. Rainey FA, Donnison AM, Janssen PH, Saul D, Rodrigo A, Bergquisr PL, Daniel RM, Stackebrandt E, Morgan HW: Description of Caldicellulosiruptor saccharolyticus gen. nov., sp. nov: an obligately anaerobic, extremely thermophilic, cellulolytic bacterium. FEMS Microbiol Lett 1994, 120:263-266.

24. NREL: Determination of structural carbohydrates and lignin in biomass. Laboratory analytical procedure (LAP). Golden CO: National Renewable Energy Laboratory; 2011.

25. Wyman CE, Dale BE, Elander RT, Holtzapple M, Ladisch MR, Lee YY, Mitchinson C, Saddler JN: Comparative sugar recovery and fermentation data following pretreatment of poplar wood by leading technologies. Biotechnol Prog 2009, 25:333-339.

26. Sato K, Goto S, Yonemura S, Sekine K, Okuma E, Takagi Y, Hon-Nami K, Saiki T: Effect of yeast extract and vitamin $B_{12}$ on ethanol production from cellulose by Clostridium thermocellum I-1-B. Appl Environ Microbiol 1992, 58:734-736.

27. Sato K, Tomita M, Yonemura S, Goto S, Sekine K, Okuma E, Takagi Y, HonNami K, Saiki T: Characterization of and ethanol hyper-production by Clostridium thermocellum I-1-B. Biosci Biotech Biochem 1993, 57:2116-2121.

28. Wiegel J, Ljungdahl LG: Thermoanaerobacter ethanolicus gen nov., spec. nov., a new, extremely thermophilic, anaerobic bacterium. Arch Microbiol 1981, 128:343-348.

29. Wiegel J, Ljungdahl LG, Rawson JR: Isolation from soil and properties of the extreme thermophile Clostridium thermohydrosulfuricum. J Bacteriol 1979, 139:800-810

30. Van de Werken HJ, Verhaart MR, VanFossen AL, Willquist K, Lewis DL, Nichols JD, Goorissen HP, Mongodin EF, Nelson KE, van Niel EW, Stams AJ, Ward DE, de Vos WM, van der Oost J, Kelly RM, Kengen SW: Hydrogenomics of the extremely thermophilic bacterium Caldicellulosiruptor saccharolyticus. Appl Environ Microbiol 2008, 74:6720-6729.
31. VanFossen AL, Verhaart MR, Kengen SM, Kelly RM: Carbohydrate utilization patterns for the extremely thermophilic bacterium Caldicellulosiruptor saccharolyticus reveal broad growth substrate preferences. Appl Environ Microbiol 2009, 75:7718-7724.

32. Dam P, Kataeva I, Yang SJ, Zhou F, Yin Y, Chou W, Poole FL 2nd, Westpheling J, Hettich R, Giannone R, Lewis DL, Kelly R, Gilbert HJ, Henrissat $B, X u Y$, Adams MW: Insights into plant biomass conversion from the genome of the anaerobic thermophilic bacterium Caldicellulosiruptor bescii DSM 6725. Nucleic Acids Res 2011, 39:3240-3254.

33. Lynd LR, Baskaran S, Casten S: Salt accumulation resulting from base added for $\mathrm{pH}$ control, and not ethanol, limits growth of Thermoanaerobacterium thermosaccharolyticum HG-8 at elevated feed xylose concentrations in continuous culture. Biotechnol Prog 2001, 17:118-125.

34. Willquist $\mathrm{K}$, Claassen PAM, van Niel EWJ: Evaluation of the influence of $\mathrm{CO}_{2}$ as stripping gas on the performance of the hydrogen producer Caldicellulosiruptor saccharolyticus. Int J Hydrogen Energy 2009, 34:4718-4726.

35. Chung D, Farkas J, Huddleston JR, Olivar E, Westpheling J: Methylation by a unique a-class N4-cytosine methyltransferase is required for DNA transformation of Caldicellulosiruptor bescii DSM6725. PLoS One 2012, 7:e43844.

36. Farkas J, Chung D, Cha M, Copeland J, Grayeski P, Westpheling J: Improved growth media and culture techniques for genetic analysis and assessment of biomass utilization by Caldicellulosiruptor bescii. J Ind Microbiol Biotechnol 2013, 40:41-49.

37. Hungate RE: A roll tube method for cultivation of strict anaerobes. Methods Microbiol 1969, 3B:117-132.

38. Lane DJ: 16S/23S rRNA sequencing. In Nucleic Acid Techniques in Bacterial Systematics. Edited by Stackebrandt E, Goodfellow M. Chichester: Wiley; 1991:115-175.

39. Saitou N, Nei M: The neighbor-joining method: a new method for reconstructing phylogenetic trees. Mol Bio Evol 1987, 4:406-425.

40. Tamura K, Dudley J, Nei M, Kumar S: MEGA4: Molecular Evolutionary Genetics Analysis (MEGA) software version 4.0. Mol Biol Evol 2007, 24:1596-1599.

41. Shaw AJ, Hogsett DA, Lynd LR: Identification of the [Fe-Fe]-hydrogenase responsible for hydrogen generation in Thermoanaerobacterium saccharolyticum and demonstration of increased ethanol yield via hydrogenase knockout. J Bacteriol 2009, 191:6457-6464.

doi:10.1186/1754-6834-6-31

Cite this article as: Svetlitchnyi et al: Single-step ethanol production from lignocellulose using novel extremely thermophilic bacteria. Biotechnology for Biofuels 2013 6:31.

\section{Submit your next manuscript to BioMed Central and take full advantage of:}

- Convenient online submission

- Thorough peer review

- No space constraints or color figure charges

- Immediate publication on acceptance

- Inclusion in PubMed, CAS, Scopus and Google Scholar

- Research which is freely available for redistribution

Submit your manuscript at www.biomedcentral.com/submit
C) Biomed Central 